\title{
Insecticidal and Nematicidal Contributions of Mexican Flora in the Search for Safer Biopesticides
}

\author{
Beatriz Hernández-Carlos ${ }^{1}$ and Marcela Gamboa-Angulo ${ }^{2, *}$ (i) \\ 1 Instituto de Agroindustrias, Universidad Tecnológica de la Mixteca, Huajuapan de León, \\ Oaxaca 69000, Mexico; bhcarlos@mixteco.utm.mx \\ 2 Unidad de Biotecnología, Centro de Investigación Científica de Yucatán, Calle 43 No. 130, Col. Chuburná, \\ Mérida 97200, Mexico \\ * Correspondence: mmarcela@cicy.mx; Tel.: +52-999-942-8330
}

Received: 31 January 2019; Accepted: 26 February 2019; Published: 4 March 2019

\begin{abstract}
Plant metabolites have been used for many years to control pests in animals and to protect crops. Here, we reviewed the available literature, looking for the species of Mexican flora for which extracts and metabolites have shown activity against pest insects and parasitic nematodes of agricultural importance, as well as against nematodes that parasitize domestic cattle. From 1996 to 2018, the search for novel and eco-friendly biopesticides has resulted in the identification of 114 species belonging to 36 botanical families of Mexican plants with reported biological effects on 20 insect species and seven nematode species. Most plant species with detected pesticide properties belong to the families Asteraceae, Fabaceae, and Lamiaceae. Eighty-six metabolites have been identified as pesticidal active principles, and most have been terpenoids. Therefore, the continuation and intensification of this area of research is very important to contribute to the generation of new products that will provide alternatives to conventional pesticide agents. In addition, future studies will contribute to the recognition and dissemination of the importance of propagating plant species for their conservation and sustainable use.
\end{abstract}

Keywords: asteraceae; Haemonchus; insecticides; Meloidogyne; mexican plants; nematicides; pesticides; plant extracts; Spodoptera

\section{Introduction}

Pest control in the agricultural sector requires a greater number of alternative products that meet food safety, sustainability, and environmental care requirements. One of the strategies used to obtain new natural agents for protecting crops and domestic animals is the exploration of a diversity of plants and their metabolites [1,2]. Natural products with pesticidal properties have been demonstrated to be an important source of compounds which are used as raw materials in the development of new protective agents, both in their natural form or as semisynthetic derivatives exhibiting better effects. In addition, the chemical structures of the active components of natural products have guided the synthesis of other active compounds [3]. The exploration and use of natural products are currently increasing, with a greater focus on identifying metabolites for use in the treatment of human diseases, including parasistism and plant diseases, as well as products for use in pest control in the agricultural sector [4-9].

The biotic wealth of Mexico, which includes large tropical zones, is widely recognized as being among the greatest in the world, with Mexico harbouring an estimated 23,314 species of native vascular plants, approximately $49.8 \%$ of which are endemic [10]. Nevertheless, the amount of biodiversity prospecting for natural products in Mexico is low, and as in other countries, it has primarily focused on the search for products to control diseases or plagues that affect humans [11-13]. With respect to agricultural applications, most studies have focused on identifying antimicrobial agents rather 
than insecticides, nematicides, and herbicides [5,13-15]. Regarding plants with insecticidal properties, the results of previous studies have identified 24 Mexican plant species with pesticidal potentials that are used in different regions of the country, many of which have been identified as medicinal plants by ethnobotanical antecedents [16]. In contrast, few botanical prospecting studies have been performed to identify plants with activities against phyto and zoonematode pests. Worldwide, few plant extracts have been shown to have an acaricidal activity, three of which are from Mexican flora and were tested on Rhipicephalus microplus, and only seven pure natural compounds have been identified as active principles [17]. Undoubtedly, Tagetes erecta (Asteraceae), a native plant of Mesoamerica, is currently recognized as one of the most promising plant species given its diverse biological activities against human and plant pathogens as well as against multiple pests $[9,18]$.

Therefore, this work reviews the Mexican flora with extracts or secondary metabolites that have shown biological activity against pest insects or parasitic nematodes. Some plant species that were introduced to Mexico, such as Allium sativum, Azadirachta indica, and Ricinus communis, among others, are also discussed. The information was compiled from all of the electronic databases available at the institution, which included Google Scholar, SciFinder, PubMed, Redylac, Scopus, and Science Direct, among others.

\section{Insecticidal Compounds and Plant Extracts}

Research on natural products for controlling pest insects that affect plants has led to the identification of 85 plant species with extracts and metabolites that are effective against at least one of the evaluated targets. These plants belong to 26 botanical families, predominantly Asteraceae (31\%), Lamiaceae (14\%), Meliaceae (7\%), Annonaceae (6\%), Chenopodiaceae (6\%), Fabaceae $(5 \%)$, and Rutaceae $(5 \%)$, with the rest belonging to the families Acanthaceae, Anacardiaceae, Asparagaceae, Bignoniaceae, Brassicaceae, Burseraceae, Cactaceae, Caricaceae, Convolvulaceae, Euphorbiaceae, Lauraceae, Magnoliaceae, Papaveraceae, Petiveraceae, Piperaceae, Phytolaccaceae, Poaceae, Solanaceae, and Verbenaceae ( $<5 \%$ each).

Twenty pest insects were evaluated in the reviewed studies. The maize pest Spodoptera frugiperda J.E. Smith (Lepidoptera: Noctuidae) is the most frequently tested target together with Spodoptera littoralis Boisduval (Lepidoptera: Noctuidae) and Spodoptera exigua Hübner (Lepidoptera: Noctuidae), collectively representing $30 \%$ of the target pests assayed in the reviewed studies, and these species were followed by Sitophilus zeamais Motschulsky (Coleoptera: Curculionidae, 14\%), the sucker Bemisia tabaci Gennadius (Homoptera: Aleyrodidae, 11\%), and Trialeurodes vaporariorum West. (Homoptera: Aleyrodidae, 7\%). The remaining targets included Anastrepha ludens Loew (Diptera: Tephritidae), Bactericera cockerelli (Hemiptera: Psylloidea), Copitarsia decolora Guenée (Lepidoptera: Noctuidae), Dactylopius opuntiae Cockerell (Hemiptera: Coccoidea), Leptinotarsa decemlineata Say (Coleoptera: Chrysomelidae), Prostephanus truncatus Horn (Coleoptera: Bostrichidae), Scyphophorus acupunctatus Gyllenhaal (Coleoptera: Curculionidae), Stomoxys calcitrans Linneo (Diptera: Muscidae), Tenebrio molitor Linnaeus (Coleoptera: Tenebrionidae), Trichoplusia ni Hübner (Lepidoptera: Noctuidae), and Zabrotes subfasciatus Boheman (Coleoptera: Bruchidae). Other targets assayed included Aedes aegypti Linnaeus, Anopheles albimanus C.R.G. Wiedemann, and Culex quinquefasciatus Say (Diptera: Culicidae), which have been included in this review because they are all very important pest insects of humans and are also virus vectors.

In this review, first, the insecticidal compounds isolated and identified in enriched fractions (as alkaloids and terpenes) and essential oils (EOs) from Mexican plants are described by the targeted pests. The second part includes plant extracts which the active principles of are not yet known.

\subsection{Spodoptera sp.}

During investigations carried out on the control of Spodoptera sp. (S. frugiperda and S. littoralis), 43 effective natural compounds have been identified including terpenes (1-30), flavonoids (31-35), stilbenes (36-38), a coumarin (39), a ketone (40), and fatty acids (41-44). In addition, enriched fractions with metabolites that were identified as alkaloids (45-50) have been described. All of these compounds were 
isolated from 21 plant species and exhibited different degrees of effectiveness against the assayed pest insects, with the most active metabolites obtained from plants of the Asteraceae family (Cedrela dugessi, Cedrela salvadorensis, Gutierrezia microcephala, Parthenium argentatum, and Roldana barba-johannis), the Fabaceae family (Lupinus aschenbornii, Lupinus montanus, and Lupinus stipulates), and the Asparagaceae family (Yucca periculosa), which induced the strongest median lethal concentration ( $\mathrm{LC}_{50} \leq 65 \mathrm{ppm}$ ) against $S$. frugiperda. Other plant species with minor activities against $S$. frugiperda included Carica papaya, Crescentia alata, Lippia graveolens, Myrtillocactus geometrizans, Ricinus communis, Ruta graveolens, Vitex Hemsley, and Vitex mollis. In addition, five species from the genus Salvia and a member of the family Asteraceae (Senecio toluccanus) were found to have active compounds against S. littoralis.

\subsubsection{Terpenes}

The tocotrienols and hydroquinones isolated from the methanol extract (MEx) of the aerial parts of R. barba-johannis (Asteraceae) included sargachromenol (1), methyl and acetyl sargachromenol derivatives $(2,3)$, sargahydroquinoic acid (4), methyl and acetyl sargahydroquinoic acid derivatives $(5,6)$, and sargaquinoic acid (7). Metabolites 1,3 , and $\mathbf{6}$ showed potent insecticidal activity against the fifth-stage larvae of $S$. frugiperda, with median lethal dose $\left(\mathrm{LD}_{50}\right)$ values of $2.94,3.89$, and $4.83 \mathrm{ppm}$, respectively. Metabolite 4 was most effective against first-instar $S$. frugiperda larvae, with a $\mathrm{LC}_{50}$ of $5.77 \mathrm{ppm}$. Furthermore, acetylated metabolite 3 was the most potent compound against the emergence of $S$. frugiperda adults from pupae, while the efficacy was further increased using a mixture of acetylated compounds $\mathbf{1}, \mathbf{3}$, and $7\left(\mathrm{LD}_{50}=3.26 \mathrm{ppm}\right)$ [19]. Furthermore, Cespedes [20] identified two cycloarten-type triterpenes, argentatin A (8) and argentatin B (9), from a methanol extract (MEx) of the aerial parts of P. argentatum. Although both metabolites showed good insecticidal and growth inhibition activities, the MEx was consistently more potent than either triterpene alone. Methanol extract, 8, and 9 showed a potent toxicity towards $S$. frugiperda adults, with $\mathrm{LD}_{50}$ values of 3.1, 12.4, and $19.8 \mathrm{ppm}$, respectively. In addition, the insecticidal activities of MEx and compound $\mathbf{8}$ against the fifth-instar larvae of $S$. frugiperda were tested, with $\mathrm{LC}_{50}$ values of 6.4 and $17.8 \mathrm{ppm}$ and median mortality concentration $\left(\mathrm{MC}_{50}\right)$ values of 6.9 and $21.3 \mathrm{ppm}$, respectively. In agreement with these results, the observed growth and relative growth indices seven days after treatment with both metabolites and MEx revealed a delay in the time of $S$. frugiperda pupation and adult emergence and an increase in deformities. Acetylcholinesterase inhibition ( $83.5 \%$ and $100 \%$ ) was observed using MEx at 5 and 25 ppm, respectively, but not for the pure compounds ( $90-100 \%$ at $50 \mathrm{ppm}$ ).

The G. microcephala clerodane diterpene bacchabolivic acid (10) and its synthetic methyl ester (10a) were shown to cause significant mortality $\left(\mathrm{MC}_{50}=10.7\right.$ and $3.46 \mathrm{ppm}$, respectively) towards $S$. frugiperda neonatal larvae, good toxicity against adults $\left(\mathrm{LD}_{50}=6.59\right.$ and $15.05 \mathrm{ppm}$, respectively), and moderate acetylcholinesterase inhibitory activity [21]. The leaves of two Meliaceae species, C. salvadorensis and C. dugessi, were shown to produce a mixture of photogedunin $\alpha$ and $\beta(\mathbf{1 1}, \mathbf{1 2})$ and gedunin $(\mathbf{1 3})$. The mixture of compounds $\mathbf{1 1}$ and 12, as well as $\mathbf{1 3}$ and its acetate derivative (13a), caused good S. frugiperda larval mortality ( $\mathrm{LC}_{50}=10,8$, and $39 \mathrm{ppm}$, respectively) [22]. A labdane-type anticopalic acid (14) from Vitex hemsleyi showed an effective antifeedant dose of $90.6 \mathrm{ppm}$ against sixth-instar S. frugiperda larvae [23]. Sterols isolated from the aerial parts of $M$. geometrizans (Cactaceae), including macdougallin (15), peniocerol (16), and a mixture of the two metabolites 15:16 (4:6), displayed a high toxicity towards S. frugiperda $\left(\mathrm{LD}_{95}=285,125\right.$, and $135 \mathrm{ppm}$, respectively). In addition, at $20 \mathrm{ppm}$, the mixture of $\mathbf{1 5}$ and $\mathbf{1 6}$ drastically resulted in the total inhibition of S. frugiperda pupation and the emergence of adults [24].

Terpenes with noticeable activity against $S$. frugiperda (100 ppm: $65-80 \%$ larval mortality) have been identified in enriched fractions from Crescentia alata, including ningpogenin (17), $\beta$-sitosterol (18), stigmasterol (19), and $6 \beta, 7 \beta, 8 \alpha, 10$-tetra- $p$-hydroxybenzoyl-cis-2-oxabicycle-(4.3.0)nonan-3-one (20) $[25,26]$. Guevara [27] reported that monoterpenes thymol (21) and carvacrol (22) were the major components in a hexanic extract of $L$. graveolens leaves. This extract caused deformations in S. frugiperda adults at different concentrations (10-100 ppm). 
The pest $S$. littoralis was also shown to be sensitive to seven antifeedant clerodane-type diterpenoids obtained from several Salvia species $\left(\mathrm{AI}_{50}<90 \mathrm{ppm}\right)$. These diterpenoids included kerlinolide (23); 1(10)-dehydrosalviarin (24) from Salvia lineata; from Salvia keerlii, 13,14-dihydro-3,4 epoxy-melissodoric acid methyl ester acetate (25), $2 \beta$-acetoxy-7 $\alpha$-hydroxy-neo-clerodan-3,13-dien-18,19:16.15-diolide (26) from Salvia melissodora; salviarin (27) from Salvia rhyacophila; and 6 $\beta$-hydroxysalviarin (28) and semiatrin (29) from Salvia semiatrata. The most effective of these was 25, with an $\mathrm{AI}_{50}$ value of $1 \mathrm{ppm}$ [28]. The metabolite toluccanolide A (30), isolated from S. toluccanus, and its acetate derivative (30a) showed a significant antifeedant effect against S. littoralis (57\% and $69.6 \%$, respectively) after an application of this compound $\left(50 \mu \mathrm{g} / \mathrm{cm}^{2}\right)$ to leaves (Table 1, Figure 1) [29].

Table 1. Insecticidal terpenes from Mexican flora effective on Spodoptera sp.

\begin{tabular}{|c|c|c|c|c|}
\hline Insect & Species/Family & $\begin{array}{l}\text { Plant } \\
\text { Part }\end{array}$ & Compound/Extract (Toxicity) & Ref. \\
\hline \multirow[t]{6}{*}{ S. frugiperda } & $\begin{array}{l}\text { Roldana } \\
\text { barba-johannis * } \\
\text { Asteraceae }\end{array}$ & $\mathrm{AP}$ & 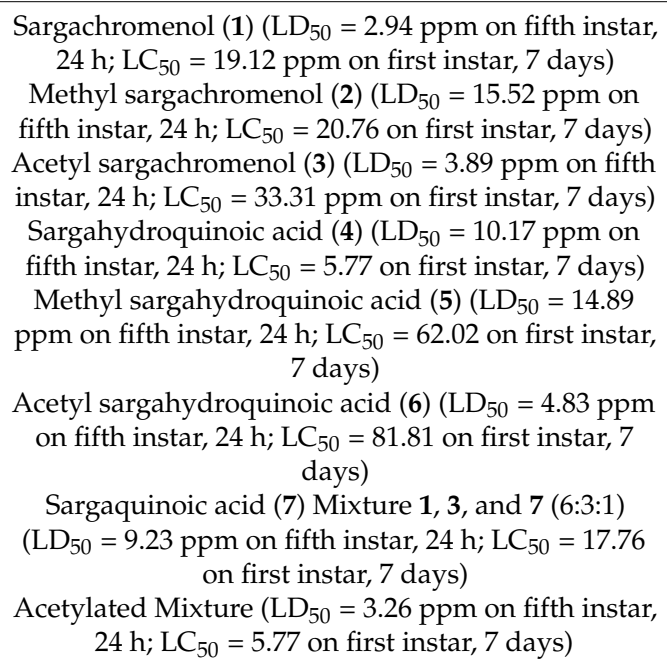 & [19] \\
\hline & $\begin{array}{l}\text { Parthenium } \\
\text { argentatum * } \\
\text { Asteraceae }\end{array}$ & $\mathrm{AP}$ & $\begin{array}{l}\text { Argentatin A (8) }\left(\mathrm{LD}_{50}=12.4 \text { ppm on fifth instar, } 24\right. \\
\left.\text { h; } \mathrm{LC}_{50}=17.8 \mathrm{ppm}, 7 \text { days; } \mathrm{MC}_{50}=21.3 \mathrm{ppm}, 7 \text { days }\right) \\
\text { Argentatin B (9) }\left(\mathrm{LD}_{50}=19.8 \mathrm{ppm} \text {, on fifth instar, } 24\right. \\
\left.\text { h; } \mathrm{LC}_{50}=36.1 \mathrm{ppm}, 7 \text { days; } \mathrm{MC}_{50}=37 \mathrm{ppm}, 7 \text { days }\right) \\
\text { Methanol }\left(\mathrm{LD}_{50}=3.1 \mathrm{ppm} \text { on fifth instar, } 24 \mathrm{~h} ; \mathrm{LC}_{50}\right. \\
\left.\quad=6.4 \mathrm{ppm}, 7 \text { days; } \mathrm{MC}_{50}=6.9 \mathrm{ppm}, 7 \text { days }\right)\end{array}$ & {$[20]$} \\
\hline & $\begin{array}{l}\text { Gutierreza } \\
\text { microcephala * } \\
\text { Asteraceae }\end{array}$ & $\mathrm{AP}$ & $\begin{array}{l}\text { Bacchabolivic acid (10) }\left(\mathrm{MC}_{50}=10.7 \mathrm{ppm}, 7 \text { days; }\right. \\
\left.\text { LD }_{50}=6.59 \mathrm{ppm}, 24 \mathrm{~h} ; 50 \mathrm{ppm}: 90.2 \% \text { IAche }\right) \\
\text { Methyl ester of } 10(\mathbf{1 0 a})\left(\mathrm{MC}_{50}=3.46 \mathrm{ppm}, 7 \text { days; }\right. \\
\left.\text { LD }_{50}=15.05 \text { ppm, } 24 \mathrm{~h} ; 50 \text { ppm: } 60 \% \text { IAche }\right)\end{array}$ & {$[21]$} \\
\hline & $\begin{array}{l}\text { Cedrela dugessi }{ }^{*} \\
\text { Meliaceae }\end{array}$ & Leaves & $\begin{array}{c}\alpha \text { and } \beta \text {-Photogedunin }(\mathbf{1 1} \text { and } \mathbf{1 2}) \text { mixture }\left(\mathrm{LC}_{50}=\right. \\
10 \mathrm{ppm}, 7 \text { days; } 19.2 \mathrm{ppm}: 88 \% \text { larval growth } \\
\text { inhibition; } 5 \text { ppm: } 23 \text { and } 85 \% \text { pupation and } \\
\text { emergence reduction) } \\
\alpha \text { and } \beta \text { - Photogedunin acetates }(\mathbf{1 1 a} \text { and } \mathbf{1 2 a}) \\
\text { mixture }\left(\mathrm{LC}_{50}=8 \mathrm{ppm}, 7 \text { days) }\right. \\
\text { Gedunin (13) }\left(\mathrm{LC}_{50}=39 \mathrm{ppm}, 7 \text { days; } 5 \text { ppm: } 91 \%\right. \\
\text { larval growth inhibition; } 5 \text { ppm: } 6.2 \text { and } 78.5 \% \\
\text { pupation and emergence reduction) }\end{array}$ & [22] \\
\hline & Cedrela salvadorensis & Leaves & $\begin{array}{l}\alpha \text { - and } \beta \text {-Photogedunin }(\mathbf{1 1} \text { and } \mathbf{1 2}), \alpha \text { - and } \beta \text { - } \\
\text { photogedunin acetates }(\mathbf{1 1 a} \text { and } \mathbf{1 2 a}) \text { mixture } \\
\text { gedunin (13) }\end{array}$ & {$[22]$} \\
\hline & $\begin{array}{l}\text { Vitex hemsleyi* } \\
\text { Lamiaceae }\end{array}$ & $\begin{array}{l}\text { Leaves } \\
\text { Stem }\end{array}$ & Anticopalic acid (14) $\left(\mathrm{EC}_{50}=90.6\right.$ ppm, L6 larvae $)$ & {$[23]$} \\
\hline
\end{tabular}


Table 1. Cont.

\begin{tabular}{|c|c|c|c|c|}
\hline Insect & Species/Family & $\begin{array}{l}\text { Plant } \\
\text { Part }\end{array}$ & Compound/Extract (Toxicity) & Ref. \\
\hline & $\begin{array}{l}\text { Myrtillocactus } \\
\text { geometrizans * } \\
\text { Cactaceae }\end{array}$ & Whole & $\begin{array}{l}\text { Macdougallin (15) }\left(\mathrm{LD}_{95}=285 \mathrm{ppm} ; 50 \mathrm{ppm}: 97.2 \%\right. \\
\text { M; 0\% pupation; } 0 \% \text { emergence) } \\
\text { Peniocerol (16) (LD } 95=125 \text { ppm; } 50 \text { ppm: } 97.2 \% \mathrm{M} \\
\text { 0\% pupation; } 0 \% \text { emergence) } \\
\text { mixture (4:6) } 15+16(\mathrm{LD} 95=135 \text { ppm; } 20 \mathrm{ppm:} \\
\text { 97.2\% M; } 0 \% \text { pupation; } 0 \% \text { emergence) }\end{array}$ & [24] \\
\hline & $\begin{array}{l}\text { Crescentia alata } \\
\text { Bignoniaceae }\end{array}$ & Fruits & $\begin{array}{c}\text { Fraction enriched with ningpogenin (17) }(100 \mathrm{ppm} \text { : } \\
80 \% \text { larval mortality); fraction enriched with: } \\
\beta \text {-sitosterol (18), stigmasterol (19) and } \\
6 \beta, 7 \beta, 8 \alpha, 10 \text {-tetra- } p \text {-hydroxybenzoyl-cis-2- } \\
\text { oxabicycle[4.3.0]nonan-3-one (20) } \\
\text { (100 ppm: } 65 \% \text { larval mortality) }\end{array}$ & $\begin{array}{l}{[25,} \\
26]\end{array}$ \\
\hline & $\begin{array}{l}\text { Lippia graveolens } \\
\text { Verbenaceae }\end{array}$ & Leaves & $\begin{array}{c}\text { Hexane (10-100 ppm: deformed adults), thymol (21, } \\
70.6 \%) \text {, carvacrol }(22,22.8 \%)\end{array}$ & {$[27]$} \\
\hline \multirow[t]{6}{*}{ S. littoralis } & $\begin{array}{l}\text { Salvia keerlii * } \\
\text { Lamiaceae }\end{array}$ & $\mathrm{AP}$ & Kerlinolide (23) $\left(\mathrm{AI}_{50}=67 \mathrm{ppm}\right)$ & {$[28]$} \\
\hline & $\begin{array}{l}\text { Salvia lineata * } \\
\text { Lamiaceae }\end{array}$ & $\mathrm{AP}$ & 1(10)-Dehydrosalviarin $\left(24, \mathrm{AI}_{50}=32 \mathrm{ppm}\right)$ & [28] \\
\hline & $\begin{array}{l}\text { Salvia melissodora } * \\
\text { Lamiaceae }\end{array}$ & $\mathrm{AP}$ & $\begin{array}{c}\text { 13,14-Dihydro-3,4 epoxy-melissodoric acid methyl } \\
\text { ester acetate }(25)\left(\mathrm{AI}_{50}=1 \mathrm{ppm}\right) \\
\text { 2- } \beta \text {-acetoxy-7 } \alpha \text {-hydroxy-neo-clerodan-3,13- } \\
\text { dien-18,19:16.15-diolide }(26)\left(\mathrm{AI}_{50}=84 \mathrm{ppm}\right)\end{array}$ & {$[28]$} \\
\hline & $\begin{array}{l}\text { Salvia rhyacophila* } \\
\text { Lamiaceae }\end{array}$ & $\mathrm{AP}$ & $\begin{array}{c}\text { Salviarin }(27)\left(\mathrm{AI}_{50}=81 \mathrm{ppm}\right) \\
6 \beta-\text { Hydroxysalviarin }(28)\left(\mathrm{AI}_{50}=24 \mathrm{ppm}\right)\end{array}$ & [28] \\
\hline & $\begin{array}{l}\text { Salvia semiatrata * } \\
\text { Lamiaceae }\end{array}$ & $\mathrm{AP}$ & Semiatrin (29) $\left(\mathrm{AI}_{50}=87 \mathrm{ppm}\right)$ & {$[28]$} \\
\hline & $\begin{array}{l}\text { Senecio toluccanus * } \\
\text { Asteraceae }\end{array}$ & Roots & $\begin{array}{c}\text { Toluccanolide A (30) and toluccanolide A acetate } \\
\begin{array}{c}(30 a)\left(50 \mu \mathrm{g} / \mathrm{cm}^{2}:\right. \\
57 \text { and } 69.6 \% \text { antifeedant effect, } \\
\text { respectively) }\end{array}\end{array}$ & [29] \\
\hline
\end{tabular}

* Endemic; AP: Aerial parts; $\mathrm{AI}_{50}=$ Median antifeedant index; $\mathrm{EC}_{50}=$ Effective antifeedant concentration; $\mathrm{GD}_{50}=$ Median Growth Dose; $\mathrm{ID}_{50}=$ Median Inhibitory Dose; $\mathrm{LC}_{50}=$ Median Lethal Concentration; LD $\mathrm{D}_{50}=$ Median Lethal Dose; $\mathrm{LV}_{50}=$ Median Larval Viability; IAche: Inhibition of acetylcholinesterase; $\mathrm{MC}_{50}=\mathrm{Median}$ Mortality Concentration. 

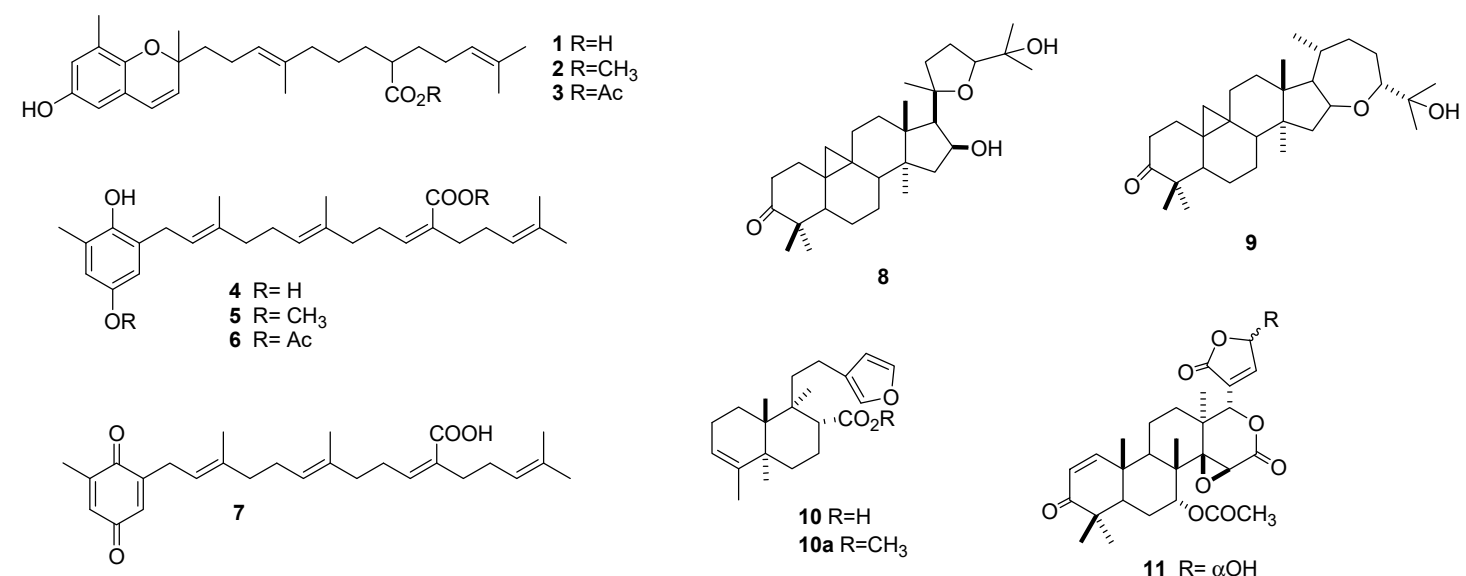

$\begin{array}{ll}11 & \mathrm{R}=\alpha \mathrm{OH} \\ 12 \mathrm{R}=\beta \mathrm{OH}\end{array}$

11a $\mathrm{R}=\alpha \mathrm{OCOCH}_{3}$
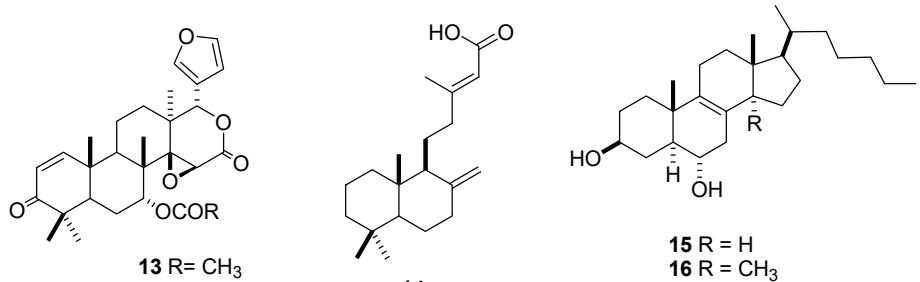

12a $\mathrm{R}=\mathrm{BOCOCH}_{3}$

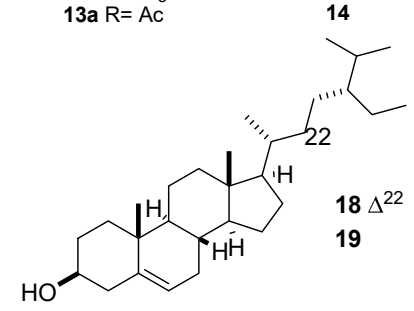

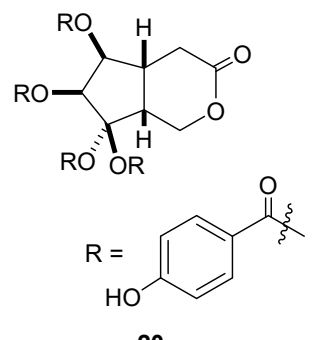<smiles>Cc1ccc(C(C)C)c(O)c1</smiles><smiles>Cc1ccc(O)cc1C</smiles>

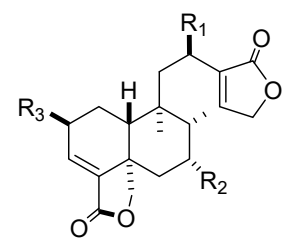

$$
\begin{aligned}
& 23 \mathrm{R}_{1}=\mathrm{b}-\mathrm{OH}, \mathrm{R}_{2}=\mathrm{a}-\mathrm{OOCCH} \mathrm{C}_{3} \\
& 26 \mathrm{R}_{1}=\mathrm{H}, \mathrm{R}_{2}=\mathrm{OH}, \mathrm{R}_{3}=\mathrm{OCOCH}_{3} \\
& 29 \mathrm{R}_{1}=\mathrm{OH}, \mathrm{R}_{2}=\mathrm{H}, \mathrm{R}_{3}=\mathrm{OH}
\end{aligned}
$$<smiles></smiles>

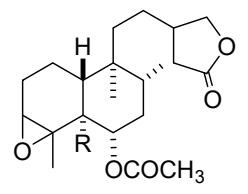

$25 \mathrm{R}=\mathrm{CO}_{2} \mathrm{CH}_{3}$

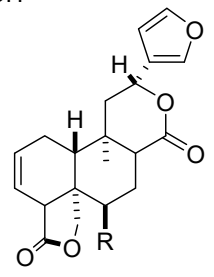<smiles>CC1=C(C)C2=C(CC3=CCCC(C)C32O)OO1</smiles>

\begin{tabular}{ll} 
& \multicolumn{2}{l}{} \\
30 & $\mathrm{H}$ \\
$30 \mathrm{a}$ & $\mathrm{Ac}$
\end{tabular}

$$
\begin{aligned}
& 27 \mathrm{R}=\mathrm{H} \\
& 28 \mathrm{R}=\mathrm{OH}
\end{aligned}
$$

Figure 1. Terpenes with activity on Spodoptera sp.

\subsubsection{Flavonoids}

Flavonoids isolated from the aerial parts of G. microcephala exhibited moderate effects against S. frugiperda, with these compounds including 5,7,2'-trihydroxy-3,6,8,4',5'-pentamethoxyflavone (31), 5,7,4'-trihydroxy-3,6,8-trimethoxyflavone (32), 5,7,2', $4^{\prime}$-tetrahydroxy-3,6,8,5'-tetramethoxyflavone (33), and 5,2'-dihyhydroxy-3,6,7,8, $4^{\prime}, 5^{\prime}$-hexamethoxyflavone (34). Flavone 31 displayed the lowest LC $_{50}$ 
value (3.9 ppm) against neonatal S. frugiperda larvae [21]. In addition, flavones 31-34 exhibited $93.7-100 \%$ acetylcholinesterase inhibitory activity at 50 ppm (Table 2, Figure 2).

Table 2. Insecticidal flavonoids from Mexican flora effective on Spodoptera frugiperda.

\begin{tabular}{|c|c|c|c|}
\hline Species/Family & Plant Part & Compound (Toxicity) & Ref. \\
\hline $\begin{array}{c}\text { Gutierreza microcephala * } \\
\text { Asteraceae }\end{array}$ & $\mathrm{AP}$ & 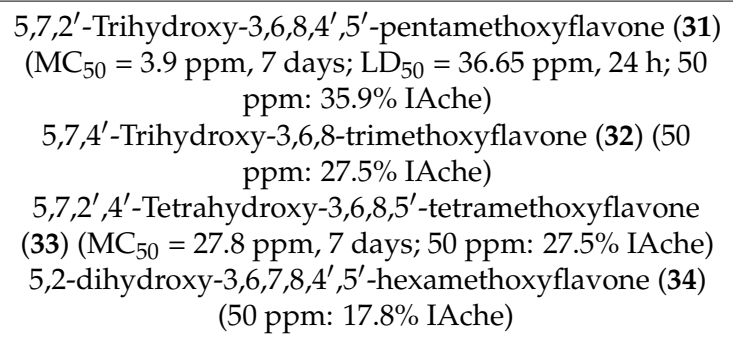 & [21] \\
\hline
\end{tabular}

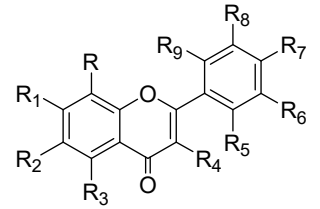

$31 \mathrm{R}=\mathrm{R}_{2}=\mathrm{R}_{4}=\mathrm{R}_{6}=\mathrm{R}_{7}=\mathrm{OCH}_{3} ; \mathrm{R}_{1}=\mathrm{R}_{3}=\mathrm{R}_{8}=\mathrm{OH} ; \mathrm{R}_{5}=\mathrm{R}_{9}=\mathrm{H}$ $32 \mathrm{R}=\mathrm{R}_{2}=\mathrm{R}_{4}=\mathrm{OCH}_{3} ; \mathrm{R}_{1}=\mathrm{R}_{3}=\mathrm{R}_{7}=\mathrm{OH} ; \mathrm{R}_{5}=\mathrm{R}_{6}=\mathrm{R}_{8}=\mathrm{R}_{9}=\mathrm{H}$ $33 \mathrm{R}=\mathrm{R}_{2}=\mathrm{R}_{4}=\mathrm{R}_{8}=\mathrm{OCH}_{3} ; \mathrm{R}_{1}=\mathrm{R}_{3}=\mathrm{R}_{5}=\mathrm{R}_{7}=\mathrm{OH} ; \mathrm{R}_{6}=\mathrm{R}_{9}=\mathrm{H}$ $34 \mathrm{R}=\mathrm{R}_{1}=\mathrm{R}_{2}=\mathrm{R}_{4}=\mathrm{R}_{7}=\mathrm{R}_{8}=\mathrm{OCH}_{3} ; \mathrm{R}_{3}=\mathrm{R}_{5}=\mathrm{OH} ; \mathrm{R}_{6}=\mathrm{R}_{9}=\mathrm{H}$ $35 R=R_{2}=R_{5}=R_{6}=R_{9} ; R_{1}=R_{3}=R_{7}=R_{8} ; R_{4}=$ GIc-Rha

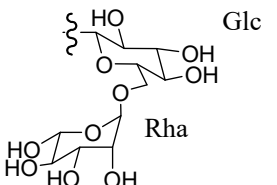

Figure 2. Insecticidal flavonoids (31-35) and stilbenes (36-38) effective on Spodoptera frugiperda.

Rutin (35) is a flavonol glycoside-reported R. graveolens constituent (Figure 2), which was also tested and showed no effect towards $S$. frugiperda [30].

\subsubsection{Stilbenes}

Stilbenes identified from the bark of $Y$. periculosa (Asparagaceae) included resveratrol (36), 4, $4^{\prime}$-dihydroxystilbene (37), and 3,3',5,5'-tetrahydroxy-4-methoxystilbene (38), with 38 being the most potent and exhibiting an $\mathrm{LC}_{50}$ value of $5.4 \mathrm{ppm}$ towards neonatal larvae at seven days and a median growth inhibition $\left(\mathrm{GI}_{50}\right)$ value of $3.45 \mathrm{ppm}$ at 21 days (Table 3, Figure 2) [31].

Table 3. Stilbenes from Mexican flora active on Spodoptera frugiperda.

\begin{tabular}{|c|c|c|c|}
\hline Species/Family & Plant Part & Compound (Toxicity) & Ref. \\
\hline $\begin{array}{c}\text { Yucca periculosa * } \\
\text { Asparagaceae }\end{array}$ & Bark & $\begin{array}{c}\text { Resveratrol }(36)\left(\mathrm{LD}_{50}=24.1 \mathrm{ppm}, 24 \mathrm{~h} ; \mathrm{GI}_{50}=5.94\right. \\
\left.\text { ppm, } 21 \text { days; } \mathrm{LC}_{50}=6.4 \mathrm{ppm}, 7 \text { days }\right) \\
4,4^{\prime} \text {-Dihydroxystilbene }(37)\left(\mathrm{LD}_{50}=38 \mathrm{ppm}, 24 \mathrm{~h} ;\right. \\
\left.\mathrm{GI}_{50}=9.24 \mathrm{ppm}, 21 \text { days; } \mathrm{LC}_{50}=27.6 \mathrm{ppm}, 7 \text { days }\right) \\
3,3^{\prime}, 5,5^{\prime} \text {-Tetrahydroxy-4-methoxystilbene }(38)\left(\mathrm{LD}_{50}\right. \\
=10.1 \mathrm{ppm}, 24 \mathrm{~h} ; \mathrm{GI}_{50}=3.45 \mathrm{ppm}, 21 \text { days; } \mathrm{LC}_{50}= \\
5.4 \mathrm{ppm}, 7 \text { days })\end{array}$ & {$[31]$} \\
\hline
\end{tabular}

\subsubsection{Coumarin and Ketone}

The leaves of R. graveolens were shown to produce psoralen (39) and a median chain ketone 2-undecanone (40), both of which were effective against neonatal S. frugiperda larvae. However, metabolite 39 was more potent than 40, with larval mortalities of $100 \%$ and $50 \%$ respectively observed at a concentration of $1 \mathrm{mg} / \mathrm{mL}$ (Table 4 ) [30]. 
Table 4. A coumarin and a ketone active on Spodoptera frugiperda.

\begin{tabular}{cccc}
\hline Species/Family & Plant Part & Compound (Toxicity) & Ref. \\
\hline Ruta graveolens Rutaceae & Leaves & Psoralen (39) $(1 \mathrm{mg} / \mathrm{mL}: 100 \%$ larval mortality) & 2-Undecanone (40) $(1 \mathrm{mg} / \mathrm{mL}: 50 \%$ larval mortality)
\end{tabular}

\subsubsection{Fatty Acids}

Additional compounds with reported activity against $S$. frugiperda include palmitic (41), oleic (42), linoleic (43), and linolenic (44) acids (Table 5), which exhibited $L_{50}$ values of $\leq 1354 \mathrm{ppm}$, with the most active compounds being unsaturated fatty acids. These active fatty acids were detected in $C$. papaya seeds and R. communis leaves grown in Mexico [32,33]. Both of these plant species are widely distributed, and R. communis is recognized for its pesticidal effects and high fatty acid content [34]. Furthermore, the powdered seed of $C$. papaya has been shown to cause larval mortality and weight reduction in S. frugiperda [35,36].

Table 5. Fatty acids with biological activity on Spodoptera frugiperda.

\begin{tabular}{|c|c|c|c|}
\hline Species/Family & Plant Part & Compound (Toxicity) & Ref. \\
\hline Carica papaya Caricaceae & Seeds & $\begin{array}{c}\text { Palmitic acid }(41)\left(\mathrm{LV}_{50}=989 \mathrm{ppm}\right) \\
\text { Oleic acid }(42)\left(\mathrm{LV}_{50}=1353.4 \mathrm{ppm}\right) \\
\text { Powder in artificial diet }(15 \%: 90 \% \text { mortality, } 72 \mathrm{~h} \text {, all } \\
\text { varieties })\end{array}$ & [32] \\
\hline $\begin{array}{l}\text { Ricinus communis } \\
\text { Euphorbiaceae }\end{array}$ & Leaves & $\begin{array}{c}\text { Linoleic acid (43) }\left(\mathrm{LV}_{50}=857 \mathrm{ppm}, 1 \text { st instar larvae }\right) \\
\text { Linolenic acid (44) }\left(\mathrm{LV}_{50}=849 \mathrm{ppm}, 1 \text { st instar larvae }\right)\end{array}$ & [33] \\
\hline
\end{tabular}

\subsubsection{Alkaloidal Fractions}

Alkaloid-enriched fractions from leaves of three species of Lupinus (Fabaceae) showed remarkable toxic effects against $S$. frugiperda $\left(\mathrm{LD}_{50}=16-70 \mathrm{ppm}\right)$. These fractions primarily contained lupanine (45), multiflorine (46), sparteine (47), aphylline (48), $\alpha$-sparteine (49), and epi-aphylline (50) (Table 6, Figure 3), with a commercial standard of 47 used during the evaluations. Interestingly, L. montanus and L. aschenbornii had high amounts of $47(640$ and $780 \mu \mathrm{g} / \mathrm{g}$, respectively), whereas it was absent from L. stipulatus, which instead contained 48 and 50 as major alkaloids ( 280 and $307 \mu \mathrm{g} / \mathrm{g}$, respectively). The alkaloidal fraction of L. stipulatus was the most toxic and fast-acting against $S$. frugiperda, with an $\mathrm{LD}_{50}$ value of $20 \mu \mathrm{g} / \mathrm{mL}$ at seven days, similar to that observed for $47\left(\mathrm{LD}_{50}=11 \mu \mathrm{g} / \mathrm{mL}\right)$ [37].

Table 6. Alkaloids effective on Spodoptera frugiperda.

\begin{tabular}{|c|c|c|c|}
\hline Plant Species/Family & Plant Part & Compound (Toxicity) & Ref. \\
\hline $\begin{array}{l}\text { Lupinus aschenbornii * } \\
\text { Fabaceae }\end{array}$ & Leaves & $\begin{array}{c}\text { Alkaloids extract }\left(\mathrm{LD}_{50}=24 \mu \mathrm{g} / \mathrm{mL}, 7 \text { days }\right) \\
\text { Lupanine }(\mathbf{4 5}, 86 \mu \mathrm{g} / \mathrm{g}), \text { multiflorine }(46,31 \mu \mathrm{g} / \mathrm{g}) \\
\text { sparteine }(47,780 \mu \mathrm{g} / \mathrm{g}) \\
47 \text { commercial standard }\left(\mathrm{LD}_{50}=11 \mu \mathrm{g} / \mathrm{mL}, 7 \text { days }\right)\end{array}$ & [37] \\
\hline $\begin{array}{l}\text { Lupinus montanus * } \\
\text { Fabaceae }\end{array}$ & Leaves & $\begin{array}{l}\text { Alkaloids extract }\left(\mathrm{LD}_{50}=65 \mu \mathrm{g} / \mathrm{mL}, 7 \text { days }\right) \\
\text { Aphylline }(48,17.6 \mu \mathrm{g} / \mathrm{g}), 45(9.2 \mu \mathrm{g} / \mathrm{g}), \alpha \text {-sparteine } \\
(49,5 \mu \mathrm{g} / \mathrm{g}), \mathbf{4 7}(640 \mu \mathrm{g} / \mathrm{g})\end{array}$ & [37] \\
\hline $\begin{array}{l}\text { Lupinus stipulates * } \\
\text { Fabaceae }\end{array}$ & Seeds & $\begin{array}{c}\text { Alkaloids extract }\left(\mathrm{LD}_{50}=20 \mu \mathrm{g} / \mathrm{mL}, 7 \text { days }\right) \\
48(280 \mu \mathrm{g} / \mathrm{g}) \text {, epi-aphylline-like }(\mathbf{5 0}, 307 \mu \mathrm{g} / \mathrm{g}), 45 \\
(11.7 \mu \mathrm{g} / \mathrm{g})\end{array}$ & [37] \\
\hline
\end{tabular}

* Endemic; $\mathrm{LD}_{50}=$ Median Lethal Dose. 
<smiles>O=c1ccc2cc3ccoc3cc2o1</smiles>

39<smiles>O=C1CCC[C@@H]2C3CC(CN12)C1CCCCN1C3</smiles>

45<smiles>CCCCCCCCCC(C)=O</smiles>

40<smiles>O=C1C=CN2CC3CC(C2)C2CCCCN2CC3C1</smiles>

46

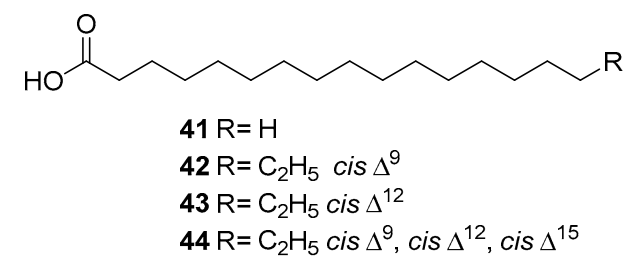<smiles></smiles>

$476 \beta$<smiles>C1CCN2CC3CC(C2)[C@H]2CCCCN2C3C1</smiles>

$4811 \beta$

$5011 \alpha$

Figure 3. Metabolites with activity on Spodoptera frugiperda.

\subsubsection{Plant Extracts with Activity against Spodoptera sp.}

The crude organic extracts of 10 plant species exhibited effective insecticidal activities against S. frugiperda, with one showing activity against S. exigua, the results of which are shown in Table 7. These plants included Bursera copallifera, Bursera grandiflora, Bursera lancifolia, Ipomoea murucoides, Ipomoea pauciflora, Salvia connivens, Salvia microphylla, Tagetes erecta, Trichilia havanensis, and Vitex mollis.

Table 7. Plant extracts from Mexican flora with activity on Spodoptera sp.

\begin{tabular}{|c|c|c|c|c|}
\hline Insect & $\begin{array}{c}\text { Plant } \\
\text { Species/Family }\end{array}$ & $\begin{array}{l}\text { Plant } \\
\text { Part }\end{array}$ & Extract (Toxicity) & Ref. \\
\hline S. exigua & $\begin{array}{l}\text { Trichilia havanensis * } \\
\text { Meliaceae }\end{array}$ & Seeds & $\begin{array}{l}\text { Oil (7000 mg/L: 56\% LM, } 12 \text { days; } 100 \mathrm{mg} / \mathrm{L}: 71.3 \% \\
\text { LWR) } \\
\text { Solid fraction (7000 mg/L: 56\% LM, } 12 \text { days; } 100 \mathrm{mg} / \mathrm{L}: \\
98.5 \% \text { LWR) }\end{array}$ & [38] \\
\hline \multirow[t]{10}{*}{ S. frugiperda } & $\begin{array}{l}\text { Bursera copallifera * } \\
\text { Burseraceae }\end{array}$ & Leaves & $\begin{array}{c}\text { Ethyl acetate (1000 ppm: 73\% LWR, } 7 \text { days; } \mathrm{IC}_{50}=553 \\
\mu \mathrm{g} / \mathrm{mL} \text { IAche) } \\
\text { Methanol (1000 ppm: 55\% LWR, } 7 \text { days; } \mathrm{IC}_{50}=367 \\
\mu \mathrm{g} / \mathrm{mL} \text { IAche) }\end{array}$ & [42] \\
\hline & & $\begin{array}{l}\text { Leaves } \\
\text { stem }\end{array}$ & $\begin{array}{c}\text { Acetonic leaves extract (500 ppm: } 47 \% \text { LM; } 50 \% \text { LWR, } 14 \\
\text { days); hexanic leaves extract (500 ppm: } 44 \% \text { deformed } \\
\text { pupae, } 14 \text { days); }\end{array}$ & [41] \\
\hline & $\begin{array}{l}\text { Bursera grandifolia* } \\
\text { Burseraceae }\end{array}$ & Leaves & $\begin{array}{c}\text { Methanol leaves extract (500 ppm: } 45 \% \text { LM; 35\% } \\
\text { deformed pupae, } 14 \text { days) }\end{array}$ & [41] \\
\hline & $\begin{array}{l}\text { Bursera lancifolia * } \\
\text { Burseraceae }\end{array}$ & Seeds & 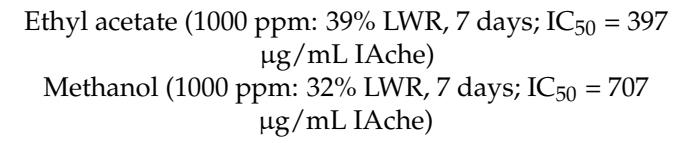 & [42] \\
\hline & $\begin{array}{l}\text { Ipomoea murucoides } \\
{ }^{*} \text { Convolvulaceae }\end{array}$ & Roots & Methanol $\left(\mathrm{LC}_{50}=2.69 \mathrm{mg} / \mathrm{mL}\right)$ & [45] \\
\hline & $\begin{array}{l}\text { Ipomoea pauciflora* } \\
\text { Convolvulaceae }\end{array}$ & Seeds & $\begin{array}{c}\text { Hexane }\left(\mathrm{LC}_{50}=1.68 \mathrm{mg} / \mathrm{mL}\right) \\
\text { Chloroform }\left(\mathrm{LC}_{50}=0.55 \mathrm{mg} / \mathrm{mL}\right)\end{array}$ & [43] \\
\hline & $\begin{array}{l}\text { Salvia connivens * } \\
\text { Lamiaceae }\end{array}$ & $\mathrm{AP}$ & Chloroform $\left(\mathrm{LV}_{50}=936 \mathrm{ppm}, 1\right.$ st instar larvae $)$ & [44] \\
\hline & $\begin{array}{l}\text { Salvia microphylla } \\
\text { Lamiaceae }\end{array}$ & $\mathrm{AP}$ & Chloroform $\left(\mathrm{LV}_{50}=916 \mathrm{ppm}, 1\right.$ st instar larvae $)$ & [44] \\
\hline & $\begin{array}{l}\text { Tagetes erecta } \\
\text { Asteraceae }\end{array}$ & Leaves & $\begin{array}{l}\text { Hexane, acetone, and ethanol }\left(\mathrm{LC}_{50}=312.2,264.9\right. \\
\text { and } 152.2 \text { ppm respectively on L1 larvae) }\end{array}$ & [40] \\
\hline & $\begin{array}{l}\text { Vitex mollis* } \\
\text { Lamiaceae }\end{array}$ & Leaves & $\begin{array}{c}\text { Dichloromethane }\left(\mathrm{LC}_{50}=46.35 \mathrm{ppm}\right) \\
\text { Chloroform-methanol 1:1 }\left(\mathrm{LC}_{50}=13.63 \mathrm{ppm}\right) \\
\text { methanol }\left(\mathrm{LC}_{50}=61.05 \mathrm{ppm}\right)\end{array}$ & [39] \\
\hline
\end{tabular}

* Endemic; $\mathrm{IC}_{50}=$ Median Inhibitory Concentration; IAche: Inhibition of acetylcholinesterase; $\mathrm{LC}_{50}=$ Median Lethal Concentration; $\mathrm{LV}_{50}=$ Median Larval Viability; LM: larval mortality; LWR: larval weight reduction. 
Against S. exigua, only the activity of an extract from T. havanensis seeds was reported, with an acetonic extract and its supernatant oil causing significant larval mortality and weight reduction. Furthermore, the acetone extract caused a noticeable delay in the development of $S$. exigua larvae when used at $500 \mathrm{mg} / \mathrm{L}$ [38].

The insecticidal activity of $V$. mollis extracts (dichloromethane, chloroform-methanol, and methanol) towards $S$. frugiperda was very interesting. A chloroform-methanol (1:1) extract from $V$. mollis leaves caused noteworthy mortality against $S$. frugiperda larvae, with an $\mathrm{LC}_{50}$ value of $13.63 \mathrm{ppm}$ observed, greater than that of previously reported terpenes (vide infra). In addition, the percentage of larvae reaching pupation decreased in the presence of all of the extracts [39]. As expected, leaf and flower extracts of $T$. erecta showed activity against $S$. frugiperda larvae. At $500 \mathrm{ppm}$, the acetonic extract from leaves was the most effective, with a 50\% reduction in larval weight observed after seven days. However, the hexane, acetone, and ethanol leaf extracts all exhibited lethal activities against $S$. frugiperda larvae, with observed $\mathrm{LC}_{50}$ values of 312.2, 246.9, and $152.2 \mathrm{ppm}$, respectively [40].

Other organic plant extracts with activity against $S$. frugiperda include acetonic extracts of B. copallifera, ethyl acetate extracts of B. lancifolia, and a methanol extract of B. grandifolia, which caused deformations in pupae or adults at different concentrations; acetylcholinesterase is also inhibited by these extracts [41,42]. In addition, I. murucoides, I. pauciflora, S. connivens, and S. microphylla extracts displayed slight effects against first-stage larvae of S. frugiperda at high concentrations (Table 7) [42-45].

\subsection{Aedes aegypti, Anopheles albimanus, and Culex quinquefasciatus}

The extracts and metabolites of 11 plant species displayed activity against the Culicides A. aegypti, A. albimanus, and C. quinquefasciatus, vectors of the human diseases, dengue fever, malaria, and lymphatic filariasis, respectively. These plant species included A. indica, Argemone mexicana, Erythrina Americana, Heliopsis longipes, Persea americana, Pseudocalymma alliaceum, Pseudosmodingium perniciosum, Ruta chalepensis, Salmea scandens, Thymus vulgaris, and Zanthoxylum fagara (Tables 8-10 and Figure 4).

\subsubsection{Alkaloids}

An alkamide named affinin (51), isolated from $H$. longipes roots, and its reduced product $N$-isobutyl-2E-decenamide (52) were moderately active against $A$. aegypti $\left(\mathrm{LC}_{50}=7.38\right.$ and $36.97 \mathrm{mg} / \mathrm{L}$, respectively). Moreover, the Coleoptera A. albimanus was more sensitive to these compounds, with $\mathrm{LC}_{50}$ values of 4.24 and $7.47 \mathrm{mg} / \mathrm{L}$, respectively. However, a crude ethanol extract displayed lower lethal activity against the larval stage of A. albimanus and A. aegypti, with $\mathrm{LC}_{50}$ values of 2.48 and $4.07 \mathrm{mg} / \mathrm{L}$, respectively (Table 8) [46]. The alkaloidal fraction from E. americana seeds induced high C. quinquefasciatus larval mortality, with an $\mathrm{LC}_{50}$ value of $87.5 \mathrm{mg} / \mathrm{L}$. After chromatographic purification, $\beta$-eritroidina (53) and erisovina (54) were obtained and tested; however, these pure compounds exhibited lower C. quinquefasciatus larvicidal activities in comparison with the alkaloidal fraction $\left(\mathrm{LC}_{50}=225\right.$ and $399 \mathrm{mg} / \mathrm{L}$, respectively) [47]. In contrast, EOs from S. scandens' stem bark caused a potent lethal effect on $A$. albimanus larvae $(2.5 \mu \mathrm{g} / \mathrm{mL})$, with the isomers $N$-isobutyl-(2E,4E,8Z,10Z)-dodecatetraenamide and $N$-isobutyl-(2E,4E,8Z,10E)-dodecatetraenamide $(55,56 ; 39.7 \%)$ constituting the majority of the compounds in this EO [48].

\subsubsection{EOs}

Among the assayed EOs, the EO obtained from leaves of $S$. scandens was the most active and had the lowest $\mathrm{LC}_{50}$ of $0.3 \mu \mathrm{g} / \mathrm{mL}$ on the larvae of A. aegypti [48]. Culex quinquefasciatus larvae were moderately sensitive to EOs from the leaves of P. americana $(800 \mathrm{mg} / \mathrm{L}: 57.5 \%$ mortality) and P. alliaceum $\left(\mathrm{LC}_{50}=385.29 \mathrm{ppm}\right)$. The EO from P. americana was observed to contain estragole (57, $61.86 \%)$, sabinene $(58,15.16 \%)$, and $\alpha$-pinene $(59,14.26 \%)$, while that of P. alliaceum consists primarily of diallyl disulphide $(\mathbf{6 0}, 50.05 \%)$, diallyl sulphide $(\mathbf{6 1}, 11.77 \%)$ and trisulphide di-2-propenyl (62, $10.37 \%$ ) (Table 8, Figure 4) [49,50]. 
Table 8. Metabolites from Mexican flora with effect against Culicidae.

\begin{tabular}{|c|c|c|c|c|}
\hline Insect & Species/Family & $\begin{array}{l}\text { Plant } \\
\text { Part }\end{array}$ & Compound/Extract (Toxicity) & Ref. \\
\hline \multirow[t]{2}{*}{ Aedes aegypti } & $\begin{array}{l}\text { Heliopsis longipes * } \\
\text { Asteraceae }\end{array}$ & Roots & $\begin{array}{c}\text { Ethanol }\left(\mathrm{LC}_{50}=4.07 \mathrm{mg} / \mathrm{L}, \mathrm{LM} 48 \mathrm{~h}\right) \\
\text { Affinin }(\mathbf{5 1})\left(\mathrm{LC}_{50}=7.38 \mathrm{mg} / \mathrm{L}, \mathrm{LM} 48 \mathrm{~h}\right) \\
\text { N-Isobutyl-2E-decenamide (52) }\left(\mathrm{LC}_{50}=36.97\right. \\
\text { mg/L, LM, } 48 \mathrm{~h})\end{array}$ & [46] \\
\hline & $\begin{array}{l}\text { Salmea scandens * } \\
\text { Asteraceae }\end{array}$ & $\begin{array}{l}\text { Stem } \\
\text { bark }\end{array}$ & 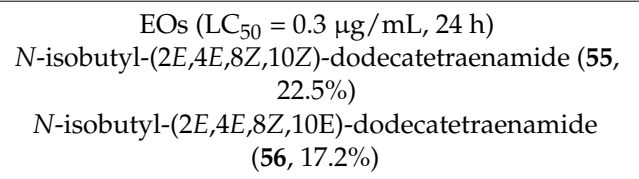 & [48] \\
\hline \multirow[t]{2}{*}{ Anopheles albimanus } & $\begin{array}{l}\text { Heliopsis longipes * } \\
\text { Asteraceae }\end{array}$ & Roots & $\begin{array}{c}\text { Ethanol }\left(\mathrm{LC}_{50}=2.48 \mathrm{mg} / \mathrm{L}, \mathrm{LM} 48 \mathrm{~h}\right) \\
\mathbf{5 1}\left(\mathrm{LC}_{50}=4.24 \mathrm{mg} / \mathrm{L}, \mathrm{LM} 48 \mathrm{~h}\right) \\
\mathbf{5 2}\left(\mathrm{LC}_{50}=7.47 \mathrm{mg} / \mathrm{L}, \mathrm{LM} 48 \mathrm{~h}\right)\end{array}$ & [46] \\
\hline & $\begin{array}{l}\text { Salmea scandens * } \\
\text { Asteraceae }\end{array}$ & $\begin{array}{l}\text { Stem } \\
\text { bark }\end{array}$ & EOs $\left(\mathrm{LC}_{50}=2.5 \mu \mathrm{g} / \mathrm{mL}, 24 \mathrm{~h}\right)$ & [48] \\
\hline \multirow[t]{3}{*}{$\begin{array}{c}\text { Culex } \\
\text { quinquefasciatus }\end{array}$} & $\begin{array}{c}\text { Erythrina americana } \\
\text { Fabaceae }\end{array}$ & Seeds & $\begin{array}{l}\text { Alkaloidal fraction }\left(\mathrm{LC}_{50}=87.5 \mathrm{mg} \mathrm{L}^{-1}, \mathrm{LM}\right) \\
\beta \text {-eritroidina }\left(53, \mathrm{LC}_{50}=225 \mathrm{mg} \mathrm{L}^{-1} ; \mathrm{LM}\right) \\
\text { Erisovina }\left(\mathbf{5 4}, \mathrm{LC}_{50}=399 \mathrm{mg} \mathrm{L}^{-1}, \mathrm{LM}\right)\end{array}$ & [47] \\
\hline & $\begin{array}{l}\text { Persea Americana } \\
\text { Lauraceae }\end{array}$ & Leaves & $\begin{array}{c}\text { EOs (50 mg/L: } 40 \% \text { mortality); }(800 \mathrm{mg} / \mathrm{L}: 57.5 \% \\
\text { mortality; RGI }=0.74) \\
\text { estragole (57) }(61.86 \%), \text { sabinene }(58,15.16 \%) \\
\alpha \text {-pinene }(\mathbf{5 9}, 14.25 \%)\end{array}$ & [49] \\
\hline & $\begin{array}{l}\text { Pseudocalymma } \\
\text { alliaceum }^{*} \\
\text { Bignonaceae }\end{array}$ & $\begin{array}{l}\text { Fresh } \\
\text { leaves }\end{array}$ & $\begin{array}{c}\text { EOs: }\left(\mathrm{LC}_{50}=385.29 \mathrm{ppm}, 48 \mathrm{~h}\right) \\
\text { hydrolat }\left(\mathrm{LC}_{50}=9.05 \%, 48 \mathrm{~h}\right) \\
\text { diallyl disulphide }(\mathbf{6 0})(50.05 \%) \text {, diallyl sulphide } \\
(\mathbf{6 1}, 11.77 \%) \text {, trisulphide di-2-propenyl }(\mathbf{6 2}, 10.37 \%)\end{array}$ & [50] \\
\hline
\end{tabular}

${ }^{*}$ Endemic; Eos = Essential Oils; LC $_{50}=$ Median Lethal Concentration; LM =Larval Mortality.

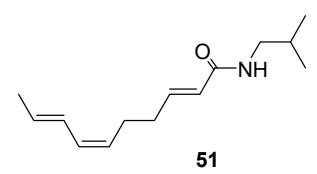

51<smiles>CCCCCCCC=CC(=O)NCC(C)C</smiles>

52

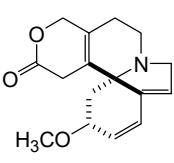

53<smiles>COc1cc2c(cc1O)CCN1CCC2C1CO</smiles>

54<smiles>C/C=C\C/C=C\CC/C=C/C=C/C(=O)NCC(C)C</smiles>

55

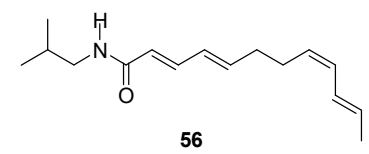

56

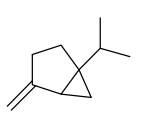

58

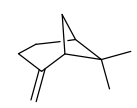

59

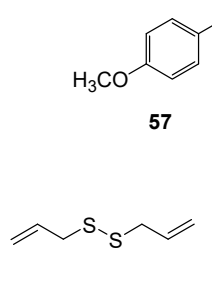

60

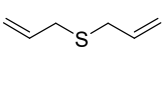

61

$$
\mathrm{NS}_{\mathrm{S}^{-}} \mathrm{S}
$$

62

Figure 4. Metabolites with effect on Aedes aegypti, Anopheles albimanus, and Culex quinquefasciatus.

\subsubsection{Plant Extracts}

The screening of extracts from six plants for activity against the fourth-instar A. aegypti larvae identified those of $A$. mexicana and P. perniciosum as the most effective (Table 9). Hexane and acetone extracts from $A$. mexicana seeds and hexane extracts from the bark of $P$. perniciosum showed the lowest larvicidal activities, with $\mathrm{LC}_{50}$ values of, 80,50 , and $20 \mu \mathrm{g} / \mathrm{mL}$, respectively [51]. Other organic extracts observed to have larvicidal activity against $A$. aegypti include those of $R$. chalepensis, T. vulgaris, and $Z$. fagara, exhibiting notable $\mathrm{LC}_{50}$ values of $1.8,4.4$ and $75.1 \mu \mathrm{g} / \mathrm{mL}$, respectively [52]. In contrast, the aqueous extract of $A$. indica showed slight effects towards four different instars of $C$. quinquefasciatus $\left(\mathrm{LD}_{50}=410-550 \mathrm{ppm}\right)$ [53]. 
Table 9. Plant extracts from Mexican flora with activity on Aedes aegypti and Culex quinquefasciatus.

\begin{tabular}{|c|c|c|c|c|}
\hline Insect & Species/Family & $\begin{array}{l}\text { Plant } \\
\text { Part }\end{array}$ & Extract (Toxicity) & Ref. \\
\hline \multirow[t]{5}{*}{ Aedes aegypti } & $\begin{array}{l}\text { Argemone mexicana } \\
\text { Papaveraceae }\end{array}$ & Seeds & $\begin{array}{l}\text { Hexane }\left(\mathrm{LC}_{50}=80 \mu \mathrm{g} / \mathrm{mL}, 48 \mathrm{~h}\right) \\
\text { acetone }\left(\mathrm{LC}_{50}=50 \mu \mathrm{g} / \mathrm{mL}, 48 \mathrm{~h}\right)\end{array}$ & {$[51]$} \\
\hline & $\begin{array}{l}\text { Pseudosmodingium } \\
\text { perniciosum * } \\
\text { Anacardiaceae }\end{array}$ & $\begin{array}{l}\text { Stem } \\
\text { Bark }\end{array}$ & Hexane $\left(\mathrm{LC}_{50}=20 \mu \mathrm{g} / \mathrm{mL}, 48 \mathrm{~h}\right)$ & {$[51]$} \\
\hline & $\begin{array}{l}\text { Ruta chalepensis } \\
\text { Rutaceae }\end{array}$ & $\begin{array}{c}\text { Aerial } \\
\text { part }\end{array}$ & $\begin{array}{c}\text { Ether and methanol }\left(\mathrm{LC}_{50}=1.8 \text { and } 6.4 \mu \mathrm{g} / \mathrm{mL},\right. \\
\text { respectively, } 24 \mathrm{~h})\end{array}$ & {$[52]$} \\
\hline & $\begin{array}{l}\text { Thymus vulgaris } \\
\text { Lamiaceae }\end{array}$ & Leaves & Ether $\left(\mathrm{LC}_{50}=4.4 \mathrm{ppm}, 24 \mathrm{~h}, 4\right.$ th instar larvae $)$ & {$[52]$} \\
\hline & $\begin{array}{l}\text { Zanthoxylum fagara } \\
\text { Rutaceae }\end{array}$ & Fruits & Ether $\left(\mathrm{LC}_{50}=75.1 \mu \mathrm{g} / \mathrm{mL}, 24 \mathrm{~h}\right)$ & {$[52]$} \\
\hline $\begin{array}{l}\text { Culex } \\
\text { quinquefasciatus }\end{array}$ & $\begin{array}{l}\text { Azadirachta indica } \\
\text { Meliacea }\end{array}$ & Seeds & $\begin{array}{l}\text { Aqueous }\left(1 \text { st instar: } \mathrm{LD}_{50}=460 \mathrm{ppm} ; 2 \text { nd instar }\right. \\
\mathrm{LD}_{50}=440 \text { ppm; } 3 \text { rd instar } \mathrm{LD}_{50}=410 \mathrm{ppm} ; 4 \text { th } \\
\left.\text { instar; } \mathrm{LD}_{50}=550 \mathrm{ppm}\right)\end{array}$ & {$[53]$} \\
\hline
\end{tabular}

* Endemic; $\mathrm{LC}_{50}=$ Median Lethal Concentration; $\mathrm{LD}_{50}=$ Median Lethal Dose.

\subsection{Anastrepha ludens}

Foliarn and stem extracts from three species of the family Annonaceae, Annona diversifolia, A. lutescens, and A. muricata, as well as one species of the family Magnoliaceae, Magnolia dealbata, showed good activity against the Mexican fruit fly A. ludens (Coleoptera). Among the assayed extracts, the aqueous extracts from stems exhibited the best effect at $100 \mu \mathrm{g} / \mathrm{mL}$, with the greatest effect $(95.9 \%)$ caused by A. lutescens (Table 10) [54,55].

Table 10. Plant extracts from Mexican flora with activity on Anastrepha ludens and Bactericera cockerelli.

\begin{tabular}{|c|c|c|c|c|}
\hline Insect & Species/Family & $\begin{array}{l}\text { Plant } \\
\text { Part }\end{array}$ & Extract (Toxicity) & Ref. \\
\hline \multirow[t]{4}{*}{ Anastrepha ludens } & $\begin{array}{c}\text { Annona diversifolia } \\
\text { Annonaceae }\end{array}$ & $\begin{array}{l}\text { Leaves } \\
\text { Stems }\end{array}$ & $\begin{array}{l}\text { Ethanol stems (1000 } \mu \mathrm{g} / \mathrm{mL}: 89.3 \% \text {, third } \\
\text { instar LM, } 72 \mathrm{~h}) \\
\text { Aqueous leaves }(100 \mu \mathrm{g} / \mathrm{mL}: 70.3 \% \text { third } \\
\text { instar LM, } 72 \mathrm{~h}) \\
\text { Aqueous stems }(1000 \mu \mathrm{g} / \mathrm{mL}: 74.3 \text { third } \\
\text { instar LM, } 72 \mathrm{~h})\end{array}$ & [54] \\
\hline & $\begin{array}{c}\text { Annona lutescens } \\
\text { Annonaceae }\end{array}$ & $\begin{array}{l}\text { Leaves } \\
\text { Stems }\end{array}$ & $\begin{array}{l}\text { Ethanol leaves }(100 \mu \mathrm{g} / \mathrm{mL}: 27.0 \% \text {, third } \\
\quad \text { instar } \mathrm{LM}, 72 \mathrm{~h}) \\
\text { Ethanol stems }(1000 \mu \mathrm{g} / \mathrm{mL}: 70.3 \% \text {, third } \\
\quad \text { instar } \mathrm{LM}, 72 \mathrm{~h}) \\
\text { Aqueous leaves }(100 \mu \mathrm{g} / \mathrm{mL}: 81.7 \% \text { third } \\
\quad \text { instar LM, 72h) } \\
\text { Aqueous stems (100 } \mu \mathrm{g} / \mathrm{mL}: 95.9 \% \text { third } \\
\text { instar LM, } 72 \mathrm{~h})\end{array}$ & [54] \\
\hline & $\begin{array}{c}\text { Annona muricata } \\
\text { Annonaceae }\end{array}$ & $\begin{array}{l}\text { Leaves } \\
\text { Stems }\end{array}$ & $\begin{array}{l}\text { Ethanol leaves }(100 \mu \mathrm{g} / \mathrm{mL}: 63.3 \% \text {, third } \\
\text { instar LM, 72 h) } \\
\text { Ethanol stems (1000 } \mu \mathrm{g} / \mathrm{mL}: 61.3 \% \text {, third } \\
\text { instar LM, 72 h) } \\
\text { Aqueous leaves }(100 \mu \mathrm{g} / \mathrm{mL}: 78.3 \% \text { third } \\
\text { instar LM, } 72 \mathrm{~h}) \\
\text { Aqueous stems }(100 \mu \mathrm{g} / \mathrm{mL}: 86.0 \text { third } \\
\text { instar LM, } 72 \mathrm{~h})\end{array}$ & {$[54]$} \\
\hline & $\begin{array}{l}\text { Magnolia dealbata } \\
\text { Magnoliaceae }\end{array}$ & $\begin{array}{l}\text { Dry } \\
\text { sarcotesta }\end{array}$ & $\begin{array}{c}\text { Ethanol }(0.1 \mathrm{mg} / \mathrm{mL}: 12.8 \% \text { survival after } 3 \\
\text { days; Abbott index: } 86.8 \% \text {, adults })\end{array}$ & [55] \\
\hline Bactericera cockerelli & $\begin{array}{l}\text { Annona muricata } \\
\text { Annonaceae }\end{array}$ & Seeds & Hexanol $\left(\mathrm{LC}_{50}=193.5 \mathrm{ppm}, 72 \mathrm{~h}\right)$ & [55] \\
\hline
\end{tabular}

$\mathrm{LC}_{50}=$ Median Lethal Concentration LM: Larval Mortality. 


\subsection{Bactericera Cockerelli}

The potato psyllid (B. cockerelli) displayed sensitivity to hexanol extracts of $A$. muricata seeds, with a lethal effect observed using 193.5 ppm after $72 \mathrm{~h}$ (Table 10) [56].

\subsection{Bemisia tabaci}

To date, five studies have reported on the use of natural Mexican plant products in whitefly (B. tabaci) management. The results of these studies identified 11 Mexican plants with extracts that are effective against various $B$. tabaci life stages (eggs, nymphs, and adults). The plant species included Acalypha gaumeri, Agave tequilana, Annona squamosa, A. indica, Capsicum chinense, Carlowrightia myriantha, C. ambrosioides, Petiveria alliacea, Piper nigrum, Pluchea sericea, and Trichilia arborea.

\section{Plant Extracts}

Cruz-Estrada [57] investigated the effects of extracts from six plant species against B. tabaci eggs and reported that aqueous extracts from the leaves of A. gaumeri, A. squamosa, P. alliacea, and T. arborea exhibited activity $\left(\mathrm{LC}_{50}=0.36-0.42 \%, w / v\right)$, as did the ethanol extracts of $P$. alliacea $\left(\mathrm{LC}_{50}=2.09\right.$ $\mathrm{mg} / \mathrm{mL})$ and T. arborea $\left(\mathrm{LC}_{50}=2.14 \mathrm{mg} / \mathrm{mL}\right)$. The latter two species showed the highest activity against B. tabaci nymphs ( $\mathrm{LC}_{50}=1.27$ and $1.61 \mathrm{mg} / \mathrm{mL}$, respectively). In parallel, leaf extracts from $A$. indica plants grown in Mexico were assayed. The toxic effects of the aqueous extracts of native plants were similar to those of $A$. indica aqueous extracts $\left(\mathrm{LC}_{50}=0.30 \%, w / v\right)$ and were greater than those of the $A$. indica ethanolic extract against eggs $\left(\mathrm{LC}_{50}=3.60 \mathrm{mg} / \mathrm{mL}\right)$ and nymphs $\left(\mathrm{LC}_{50}=2.57 \mathrm{mg} / \mathrm{mL}\right)$. A. tequilana juice (undiluted) and its hexanic extract (2\%) promoted B. tabaci nymph mortality (100\% and $91 \%$, respectively), which is interesting given the significant quantities of juice obtained from the waste of this agave (Table 11) [58].

In another study (Table 11), the ethanol extracts of mature C. chinense fruits (creole orange variety) showed slight repellency and mortality effects against $B$. tabaci adults $\left(\mathrm{LC}_{50}=29.4 \% \mathrm{w} / \mathrm{v}, \mathrm{LT}_{50}=7.31 \mathrm{~h}\right)$. The concentration of capsaicinoids in the fruit of the habanero pepper was $1193.6 \mathrm{mg} / \mathrm{kg}$. Capsaicinoids have been reported to have toxic and repellent effects against insects [59]. Ethanolic extracts from the leaves of $C$. ambrosioides and the fruits of P. nigrum showed good lethal activity against $B$. tabaci, with the lowest $\mathrm{LC}_{50}$ of $1.6 \%(w / v)$ observed for the P. nigrum extracts. Furthermore, P. nigrum produces high ethanolic extract yields (3.69\%), and this plant is inexpensive and accessible [60]. Finally, P. sericea is an interesting Asteraceae species which the extracts of have been shown to be effective against $B$. tabaci adults, with acetone, aqueous, and ethanolic extracts of the leaves shown to have moderate repellence activity $\left(\mathrm{RI}_{50}\right.$ of $\left.0.52-0.78\right)$ [61].

Table 11. Plant extracts from Mexican flora with activity on Bemisia tabaci.

\begin{tabular}{|c|c|c|c|}
\hline Species/Family & Plant Part & Extract (Toxicity) & Ref. \\
\hline $\begin{array}{l}\text { Acalypha gaumeri }{ }^{*} \\
\text { Euphorbiaceae }\end{array}$ & Leaves & $\begin{array}{c}\text { Aqueous }\left(\mathrm{LC}_{50}=0.39 \% \mathrm{w} / \mathrm{v} \text { on egg, } 48 \mathrm{~h}\right) \\
\text { Ethanol }\left(\mathrm{LC}_{50}=3.54 \mathrm{mg} / \mathrm{mL} \text { on eggs; } 3.15 \mathrm{mg} / \mathrm{mL} \text { on nymphs, } 48 \mathrm{~h}\right)\end{array}$ & [57] \\
\hline $\begin{array}{l}\text { Annona squamosa } \\
\text { Annonaceae }\end{array}$ & Leaves & $\begin{array}{c}\text { Aqueous }\left(\mathrm{LC}_{50}=0.36 \% \mathrm{w} / \mathrm{v} \text { on eggs, } 48 \mathrm{~h}\right) \\
\text { Ethanol }\left(\mathrm{LC}_{50}=2.71 \mathrm{mg} / \mathrm{mL} \text { on eggs, } 48 \mathrm{~h} ; 2.66 \mathrm{mg} / \mathrm{mL} \text { on nymphs, }\right. \\
48 \mathrm{~h})\end{array}$ & [57] \\
\hline $\begin{array}{l}\text { Agave tequilana } \\
\text { Asparagaceae }\end{array}$ & Leaves & $\begin{array}{l}\text { Juice (undiluted: } 31 \% \text { mortality on adults) } \\
\text { hexane (4\%: } 100 \% \text { mortality on adults) }\end{array}$ & [58] \\
\hline $\begin{array}{l}\text { Azadirachta indica } \\
\text { Meliacea }\end{array}$ & Leaves & $\begin{array}{c}\text { Aqueous }\left(\mathrm{LC}_{50}=0.30 \% \mathrm{w} / v \text { eggs, } 48 \mathrm{~h}\right) \\
\text { Ethanol }\left(\mathrm{LC}_{50}=4.14 \mathrm{mg} / \mathrm{mL}, \text { eggs, } 48 \mathrm{~h} ; 10 \mathrm{ppm}: 99.3 \% \text { mortality of }\right. \\
\text { nymphs })\end{array}$ & [57] \\
\hline $\begin{array}{l}\text { Capsicum chinense } \\
\text { Solanaceae }\end{array}$ & Fruits & Ethanol $\left(\mathrm{LC}_{50}=29.4 \% w / v ; \mathrm{LT}_{50}=7.31 \mathrm{~h} ; \mathrm{RI}=0.11\right)$ & [59] \\
\hline $\begin{array}{l}\text { Carlowrightia myriantha * } \\
\text { Acanthaceae }\end{array}$ & Leaves & $\begin{array}{c}\text { Aqueous }\left(\mathrm{LC}_{50}=1.1 \% \mathrm{w} / \mathrm{v} \text { on eggs }\right) \\
\text { Ethanol }\left(\mathrm{LC}_{50}=2.69 \mathrm{mg} / \mathrm{mL} \text { on eggs; } 3.10 \mathrm{mg} / \mathrm{mL} \text { on nymphs }\right)\end{array}$ & [57] \\
\hline
\end{tabular}


Table 11. Cont.

\begin{tabular}{|c|c|c|c|}
\hline Species/Family & Plant Part & Extract (Toxicity) & Ref. \\
\hline $\begin{array}{l}\text { Chenopodium ambrosioides } \\
\text { Chenopodiaceae }\end{array}$ & $\begin{array}{l}\text { Leaves } \\
\text { Stems }\end{array}$ & Ethanol $\left(\mathrm{LC}_{50}: 3.26 \% w / v\right.$, resuspended in water) & [60] \\
\hline $\begin{array}{l}\text { Petiveria alliacea } \\
\text { Petiveriaceae }\end{array}$ & $\begin{array}{l}\text { Aerial } \\
\text { part }\end{array}$ & $\begin{array}{c}\text { Aqueous }\left(\mathrm{LC}_{50}=0.42 \% \mathrm{w} / \mathrm{v} \text { on eggs }\right) \\
\text { Ethanol }\left(\mathrm{LC}_{50}=2.09 \mathrm{mg} / \mathrm{mL} \text { on eggs; } 1.27 \mathrm{mg} / \mathrm{mL} \text { on nymphs }\right)\end{array}$ & [57] \\
\hline Piper nigrum Piperaceae & Fruits & Ethanol ( $\mathrm{LC}_{50}: 1.6 \% w / v$, resuspended in water) & [60] \\
\hline Pluchea serícea Asteraceae & $\begin{array}{l}\text { Leaves } \\
\text { Stems }\end{array}$ & $\begin{array}{l}\text { Aqueous leaves }\left(\mathrm{LC}_{50}: 1190 \mathrm{ppm} ; \mathrm{RI}=0.52 \text { on adults, } 24 \mathrm{~h}\right) \\
\text { Acetone leaves }\left(\mathrm{LC}_{50}: 700 \mathrm{ppm} ; \mathrm{RI}=0.78 \text { on adults, } 24 \mathrm{~h}\right) \\
\text { Ethanol leaves }\left(\mathrm{LC}_{50}: 1250 \mathrm{ppm} \mathrm{RI}=0.66 \text { on adults, } 24 \mathrm{~h}\right) \\
\text { Aqueous stems }\left(\mathrm{LC}_{50}: 2620 \mathrm{ppm} ; \mathrm{RI}=0.54 \text { on adults, } 24 \mathrm{~h}\right)\end{array}$ & [61] \\
\hline Trichilia arborea Meliaceae & Leaves & $\begin{array}{c}\text { Aqueous }\left(\mathrm{LC}_{50}=0.39 \% w / v \text { on eggs, } 48 \mathrm{~h}\right) \\
\text { Ethanol }\left(\mathrm{LC}_{50}=2.14 \mathrm{mg} / \mathrm{mL} \text { on eggs, } 48 \mathrm{~h} ; 1.61 \mathrm{mg} / \mathrm{mL} \text { on nymphs }\right)\end{array}$ & [57] \\
\hline
\end{tabular}

* Endemic; $\mathrm{LC}_{50}$ : Median Lethal Concentration; RI: Repellency index.

\subsection{Copitarsia Decolora and Dactylopius Opuntiae}

The EOs of Beta vulgaris, C. graveolens, and Chenopodium berlandieri subsp. nuttalliae reduced the fecundity and fertility (75-99\%) of C. decolora and increased (19-38\%) the lengths of the larval and pupal periods (Table 12) [62].

Vazquez-García [63] reported that EOs obtained from Cymbopogon winterianus, L. graveolens, Mentha spicata, and Ocimum basilicum were active against the first-instar larvae of the prickly pear cochineal $D$. opuntiae, with $\mathrm{LC}_{50}$ values ranging from $0.8-6.6 \mathrm{~mL} / 100 \mathrm{~mL}$. The most effective was the EO of M. spicata, the primary constituents of which were carvone $(63,61.03 \%)$ and limonene $(64$, $15.18 \%$ ) (Table 12, Figure 5).

Table 12. Plant extracts from Mexican flora with activity against Copitarsia decolora and Dactylopius opuntiae.

\begin{tabular}{|c|c|c|c|c|}
\hline Insect & Species/Family & $\begin{array}{c}\text { Plant } \\
\text { Part }\end{array}$ & Extract (Toxicity) & Ref. \\
\hline \multirow[t]{3}{*}{ Copitarsia decolora } & $\begin{array}{l}\text { Beta vulgaris } \\
\text { Chenopodiaceae }\end{array}$ & $\begin{array}{l}\text { Stems } \\
\text { Leaves }\end{array}$ & $\begin{array}{c}\text { EOs (0.5\%: } 19 \% \text { and } 27 \% \text { increased larval } \\
\text { and pupal period length; } 99 \% \text { reduced } \\
\text { fecundity and fertility) }\end{array}$ & {$[62]$} \\
\hline & $\begin{array}{c}\text { Chenopodium } \\
\text { berlandieri subsp. } \\
\text { nuttalliae } \\
\text { Chenopodiaceae }\end{array}$ & $\begin{array}{l}\text { Whole } \\
\text { plant }\end{array}$ & $\begin{array}{l}\text { EOs }(0.5 \%: 22 \% \text { and } 38 \% \text { increased larval } \\
\text { and pupal period length; } 94 \% \text { and } 85 \% \\
\text { reduced fecundity and fertility) }\end{array}$ & [62] \\
\hline & $\begin{array}{c}\text { Chenopodium } \\
\text { graveolens } \\
\text { Chenopodiaceae }\end{array}$ & $\begin{array}{l}\text { Whole } \\
\text { plant }\end{array}$ & $\begin{array}{l}\text { EOs ( } 0.5 \%: 19 \% \text { and } 28 \% \text { reduced larval } \\
\text { and pupal period length; } 75 \% \text { and } 96 \% \\
\text { reduced fecundity and fertility) }\end{array}$ & [62] \\
\hline \multirow[t]{4}{*}{ Dactylopius opuntiae } & $\begin{array}{c}\text { Cymbopogon } \\
\text { winterianus Poaceae }\end{array}$ & Leaves & $\begin{array}{c}\mathrm{EOs}\left(\mathrm{LC}_{50}=6.6 \mathrm{~mL} / 100 \mathrm{~mL} \text { on } 1 \mathrm{st} \text { instar }\right. \\
\text { cochineal })\end{array}$ & [63] \\
\hline & $\begin{array}{l}\text { Lippia graveolens } \\
\text { Verbenaceae }\end{array}$ & Leaves & $\begin{aligned} \text { EOs }\left(\mathrm{LC}_{50}=\right. & 5.2 \mathrm{~mL} / 100 \mathrm{~mL} \text { on cochineal } \\
& \text { mobile juveniles })\end{aligned}$ & [63] \\
\hline & $\begin{array}{l}\text { Mentha spicata } \\
\text { Lamiaceae }\end{array}$ & Leaves & $\begin{array}{l}\text { EOs }\left(\mathrm{LC}_{50}=0.8 \mathrm{~mL} / 100 \mathrm{~mL} \text { solvent on }\right. \\
\text { cochineal mobile juveniles). Carvone }(\mathbf{6 3} \\
61.03 \% \text { ) and limonene }(\mathbf{6 4}, 15.18 \%)\end{array}$ & [63] \\
\hline & $\begin{array}{l}\text { Ocimum basilicum } \\
\text { Lamiaceae }\end{array}$ & Leaves & $\begin{array}{c}\text { EOs }\left(\mathrm{LC}_{50}=2.4 \mathrm{~mL} / 100 \mathrm{~mL} \text { solvent on }\right. \\
\text { cochineal mobile juveniles })\end{array}$ & [63] \\
\hline
\end{tabular}


<smiles>C=C(C)[C@H]1CC=C(C)C(=O)C1</smiles>

63<smiles>C=C(C)[C@H]1CC=C(C)CC1</smiles>

64

Figure 5. The majority components in the EOs of Mentha spicata effective on Dactylopius opuntiae.

\subsection{Leptinotarsa decemlineata}

The metabolite 6-hydroxyeuryopsin (65) isolated from $S$. toluccanus, and its acetate derivative (65a) exhibited a higher antifeedant effect ( 85 and $93.3 \%$ at $50 \mu \mathrm{g} / \mathrm{cm}^{2}$, respectively) against the Colorado potato beetle (L. decemlineata) than did S. frugiperda (vide supra) (Table 13, Figure 6) [29].

Table 13. Metabolites from Mexican flora with activity against Leptinotarsa decemlineata.

\begin{tabular}{|c|c|c|c|c|}
\hline Insect & Species/Family & Plant Part & Extract/Compound (Toxicity) & Ref. \\
\hline $\begin{array}{l}\text { Leptinotarsa } \\
\text { decemlineata }\end{array}$ & $\begin{array}{l}\text { Senecio toluccanus * } \\
\text { Asteraceae }\end{array}$ & Roots & $\begin{array}{l}\text { 6-Hydroxyeuryopsin (65) and } \\
\text { acetyloxyeuropsin }(\mathbf{6 5 a})\left(50 \mu \mathrm{g} / \mathrm{cm}^{2} \text { : }\right. \\
85.5 \% \text { antifeedant effect) }\end{array}$ & [29] \\
\hline
\end{tabular}

${ }^{*}$ Endemic; $\mathrm{LC}_{50}=$ Median Lethal Concentration.

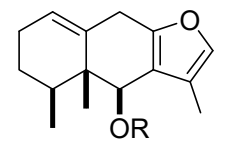

$$
\begin{array}{ll} 
& R \\
65 & H \\
65 a & A c
\end{array}
$$

Figure 6. Insecticidal metabolite 6-hydroxyeuryopsin from Senecio toluccans.

\subsection{Prostephanus truncates}

The larger grain borer ( $P$. truncates) was shown to be susceptible to EO from the leaves of Lippia palmeri, with an $\mathrm{LC}_{50}$ value of $320.5 \mu \mathrm{L} / \mathrm{L}$ observed after $72 \mathrm{~h}$. After the application of the EOs, a strong repellency against the insect at $200 \mu \mathrm{L} / \mathrm{L}$ was observed, and no insect emerged at $500 \mu \mathrm{L} / \mathrm{L}$ in $24 \mathrm{~h}$. These EOs primarily contained $22(58.9 \%)$ and $p$-cimene $(66,21.8 \%)$ as majority compounds (Table 14, Figure 7) [64].

Table 14. Essential oils from Mexican flora with activity on Prostephanus truncates.

\begin{tabular}{ccccc}
\hline Insect & Species/Family & Plant Part & Extract/Compound (Toxicity) & Ref. \\
\hline \multirow{2}{*}{$\begin{array}{c}\text { Prostephanus } \\
\text { truncates }\end{array}$} & Lippia palmeri & Leaves & EOs $\left(\mathrm{LC}_{50}=320.52 \mu \mathrm{L} / \mathrm{L}\right.$ mortality, 24 h); & \\
& Verbenaceae & carvacrol $(\mathbf{2 2}, 5.2 \%), \mathbf{2 1}(58.9 \%)$ & {$[64]$} \\
\hline
\end{tabular}

$\mathrm{LC}_{50}=$ Median Lethal Concentration<smiles>Cc1ccc(C(C)C)cc1</smiles>

Figure 7. Majority metabolite ( $p$-Cimene) from extract of Lippia palmeri. 


\subsection{Sitophilus zeamais}

The EOs of 14 plant species with activities against the stored grain pest S. zeamais were compiled. These EOs were primarily derived from members of the Asteraceae family (Aster subulatus, Bahia absinthifolia, Chrysactinia mexicana, Erigeron longipes, Eupatorium glabratum, Heliopsis annua, Heterotheca inuloides, Hippocratea celastroides, Hippocratea excelsa, Senecio flaccidus, Stevia serrata, and Zaluzania peruviana) as well as members of the Rutaceae and Verbenaceae families (Stauranthus perforates and L. palmeri, respectively).

\subsubsection{Terpenes}

The triterpenoid pristimerin (67) was isolated from the roots of $H$. excelsa and displayed a high antifeeding activity index (AAI) of $89 \%$ and slight mortality $(\mathrm{M}=16 \%)$ when used in a $1 \%$ formulation against $S$. zeamais (Table 15, Figure 8) [65].

Table 15. Plant extracts and metabolites from Mexican flora with activity against Sitophilus zeamais.

\begin{tabular}{|c|c|c|c|}
\hline Species/Family & Plant Part & Extract/Compound (Toxicity) & Ref. \\
\hline $\begin{array}{l}\text { Hippocratea excels* } \\
\text { Asteraceae }\end{array}$ & $\begin{array}{l}\text { Root } \\
\text { cortex }\end{array}$ & $1 \%$ Pristimerin $(67)(\mathrm{AAI}=89.2 \%$ and $\mathrm{M}=16 \%, 5$ days $)$ & {$[65]$} \\
\hline $\begin{array}{l}\text { Eupatorium glabratum } \\
\text { Asteraceae }\end{array}$ & Leaves & $\begin{array}{c}\text { EOs }\left(\mathrm{LC}_{50}=16 \text { (females) and } 20 \mu \mathrm{L} / \mathrm{mL} \text { (males) after } 1 \text { week); }\right. \\
\mathrm{LT}_{50}=53 \text { (females) and } 70 \mathrm{~h}(\text { males }) ; \alpha \text {-pinene }(59,29.5) \\
\alpha \text {-phellandrene }(\mathbf{6 8}, 19.6 \%)\end{array}$ & {$[66]$} \\
\hline $\begin{array}{l}\text { Lippia palmeri* } \\
\text { Verbenaceae }\end{array}$ & Leaves & $\begin{array}{c}\text { EOs }\left(\mathrm{LC}_{50}=441.45 \mu \mathrm{L} / \mathrm{L} \text { mortality, } 48 \mathrm{~h}\right) \\
p \text {-cimene }(66,21.8 \%), 21(58.9 \%)\end{array}$ & {$[64]$} \\
\hline $\begin{array}{l}\text { Aster subulatus } \\
\text { Asteraceae }\end{array}$ & Leaves & $1 \%$ Leaves powder $(\mathrm{M}=80.5 \%, 15$ days $)$ & [67] \\
\hline $\begin{array}{l}\text { Bahia absinthifolia } \\
\text { Asteraceae }\end{array}$ & Leaves & $1 \%$ powder $(\mathrm{AE}=21.6 \%, 55$ days $)$ & [67] \\
\hline $\begin{array}{l}\text { Chrysactinia mexicana } \\
\text { Asteraceae }\end{array}$ & $\begin{array}{l}\text { Leaves } \\
\text { Flower }\end{array}$ & $\begin{array}{c}1 \% \text { Leaves powder }(\mathrm{M}=80.5 \%, 15 \text { days; } \mathrm{AE}=0.0 \%, 55 \text { days }) \\
1 \% \text { Flower powder }(\mathrm{AE}=45.0 \%, 55 \text { days })\end{array}$ & [67] \\
\hline $\begin{array}{l}\text { Erigeron longipes } \\
\text { Asteraceae }\end{array}$ & Flower & $1 \%$ powder $(\mathrm{M}=88.3 \%, 15$ days $)$ & [67] \\
\hline $\begin{array}{l}\text { Heliopsis annua } \\
\text { Asteraceae }\end{array}$ & Leaves & $1 \%$ powder $(\mathrm{M}=80.6 \%, 15$ days $)$ & [67] \\
\hline $\begin{array}{l}\text { Heterotheca inuloides var. } \\
\text { rosei* Asteraceae }\end{array}$ & $\begin{array}{l}\text { Leaves } \\
\text { Flower }\end{array}$ & $\begin{array}{l}1 \% \text { Leaf powder }(\mathrm{M}=87.7 \%, 15 \text { days; } \mathrm{AE}=0.0 \%, 55 \text { days }) \\
1 \% \text { Flower powder }(\mathrm{M}=87.7 \%, 15 \text { days; } \mathrm{AE}=45.0 \%, 55 \text { days })\end{array}$ & [67] \\
\hline $\begin{array}{l}\text { Hippocratea celastroides } \\
\text { Asteraceae }\end{array}$ & Roots & $\begin{array}{c}1 \% \text { Dichloromethane }(\mathrm{AAI}=70.7 \%, 5 \text { days }) \\
1 \% \text { Hexane }(\mathrm{AAI}=67.8 \%, 5 \text { days }) \\
1 \% \text { Acetone (soluble part: } \mathrm{AAI}=72.3 \% \text {, precipitate: } \mathrm{AAI}= \\
73.9 \%, 5 \text { days })\end{array}$ & [65] \\
\hline $\begin{array}{l}\text { Senecio flaccidus } \\
\text { Asteraceae }\end{array}$ & Flower & $1 \%$ Powder $(\mathrm{M}=80.7 \%, 55$ days $)$ & [67] \\
\hline Stevia serrata Asteraceae & $\begin{array}{l}\text { Leaves } \\
\text { Flower }\end{array}$ & $\begin{array}{c}1 \% \text { Leaf powder }(\mathrm{M}=80.2 \%, 55 \text { days }) \\
1 \% \text { Flower powder }(\mathrm{M}=81.8 \%, 55 \text { days })\end{array}$ & [67] \\
\hline $\begin{array}{l}\text { Zaluzania peruviana } \\
\text { Asteraceae }\end{array}$ & $\begin{array}{l}\text { Leaves } \\
\text { Flower }\end{array}$ & $\begin{array}{l}1 \% \text { Leafs powder }(\mathrm{M}=88.1 \%, 15 \text { days; } \mathrm{AE}=50.0 \%, 55 \text { days }) \\
1 \% \text { Flower powder }(\mathrm{M}=48.3 \%, 15 \text { days; } \mathrm{AE} 40 \%, 55 \text { days })\end{array}$ & [67] \\
\hline $\begin{array}{l}\text { Stauranthus perforates } \\
\text { Rutaceae }\end{array}$ & Roots & $\begin{array}{l}\text { Powder mixed with maize kernels (1-3\%: } 91 \text {, } 95.5 \text {. and } 100 \% \\
\text { mortality respectively, } 15 \text { days) }\end{array}$ & [67] \\
\hline
\end{tabular}

* Endemic; AAI: Antifeedant Activity Index; AE: Adults emergence; M= Mortality; $\mathrm{LC}_{50}=$ Median Lethal Concentration; $\mathrm{LT}_{50}=$ Median Lethal Time. 


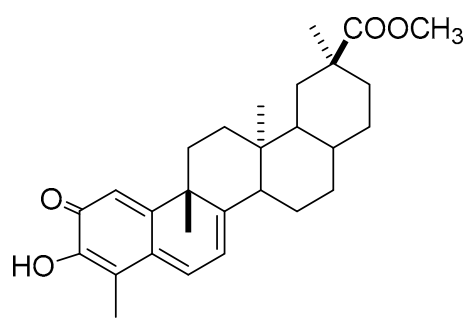

67

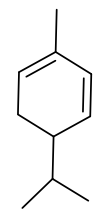

68

Figure 8. Metabolites with activity against Sitophilus zeamais.

\subsubsection{EOs}

A bioactive EO from E. glabratum exhibited high activity against female and male $S$. zeamais, with $\mathrm{LC}_{50}$ values of 16 and $20 \mu \mathrm{L} / \mathrm{mL}$, respectively, and median lethal times of 53 and $70 \mathrm{~h}$, respectively. Chromatographic analyses of E. glabratum EO revealed the presence of $\alpha$-pinene (59) and $\alpha$-phellandrene $(68,19.6 \%$ ) as the major compounds (29.5\%) [66]. In contrast, the pest insect $S$. zeamais exhibited a slight sensitivity to EO from L. palmeri leaves, with $\mathrm{LC}_{50}$ value of $441.45 \mu \mathrm{L} / \mathrm{L}$ against adults after $48 \mathrm{~h}$. In addition, this EO induced total repellency against maize weevil adults, with no emergence observed using a concentration of $1000 \mu \mathrm{L} / \mathrm{L}$ after $24 \mathrm{~h}$, with major EO components having been previously described (21 and 66) (Table 15, Figure 8) [64].

\subsubsection{Plant Extracts}

Juárez-Flores [67] screened flower powder and leaf powders from 81 plant species belonging to the Asteraceae family. Among the 162 plant powders tested $(1 \%, w / w)$, twelve powders showed remarkable lethal activities $(>80 \%)$ against $S$. zeamais, but only two inhibited adult emergence ( $<22$ insects), B. absinthifolia and C. Mexicana (Table 15). The most effective of these powders were those produced from the leaves of C. mexicana, which caused a mortality of $98 \%$ and no adult emergence. Similarly, the root powder of S. perforates mixed with maize kernel (3\%) displayed total mortality against $S$. zeamais [68], while an acetone extract produced from the roots of $H$. celastroides and its precipitate resulted in slight antifeeding activity index values of 72.3 and 73.8 against the stored grain pest S. zeamais, respectively (Table 15) [65].

\subsection{Stomoxys calcitrans and Scyphophorus acupunctatus}

The flavanone pinocembrine (69) obtained from the aerial parts of Teloxys graveolens showed an $\mathrm{LC}_{50}$ value of $418.69 \mu \mathrm{g} / \mathrm{mL}$ against the third-stage larvae of the stable fly S. calcitrans, an ectoparasite of mammals (Table 16, Figure 9) [69].

Valdés-Estrada [70] reported that seed powders (15\%) from Trichilia havanensis, C. papaya, and Annona cherimola had good effects (100, 90, and 63\%, respectively) on the mortality of the larvae of $S$. acupunctatus. All powders inhibited the weight of the agave weevil. The most effective was A. cherimola. (Table 16).<smiles>O=C1C[C@H](c2ccccc2)Oc2cc(O)cc(O)c21</smiles>

Figure 9. Metabolite effective on Stomoxys calcitrans. 
Table 16. Plant extracts and a metabolite from Mexican flora with activity on Stomoxys calcitrans and Scyphophorus acupunctatus.

\begin{tabular}{|c|c|c|c|c|}
\hline Insect & Species/Family & Plant Part & Extract/Compound (Toxicity) & Ref. \\
\hline $\begin{array}{l}\text { Stomoxys } \\
\text { calcitrans }\end{array}$ & $\begin{array}{l}\text { Teloxys graveolens } \\
\text { Chenopodiaceae }\end{array}$ & Aerial part & $\begin{array}{c}\text { Pinocembrine }(69)\left(\mathrm{LC}_{50}=418.69 \mu \mathrm{g} / \mathrm{mL}\right. \\
\text { 3rd stage larvae, } 24 \mathrm{~h})\end{array}$ & [69] \\
\hline \multirow[t]{3}{*}{$\begin{array}{l}\text { Scyphophorus } \\
\text { acupunctatus }\end{array}$} & $\begin{array}{l}\text { Annona cherimola } \\
\text { Annonaceae }\end{array}$ & Seeds & $\begin{array}{c}\text { Podwer (15\% in artificial diet: } 63 \% \mathrm{LM} \text {; } \\
\text { larval, pupal, and adult weight } \\
\text { reductions of } 98.5,40.6 \text {, and } 45.0 \%, \\
\text { respectively, } 24 \text { days) }\end{array}$ & {$[70]$} \\
\hline & $\begin{array}{c}\text { Carica papaya } \\
\text { Caricaceae }\end{array}$ & seeds & $\begin{array}{l}\text { fresh seed (15\% in artificial diet: } 90 \% \text { LM, } \\
24 \text { days) } \\
\text { dry seed powder (15\% in artificial diet: } \\
100 \% \text { LM, } 24 \text { days) }\end{array}$ & {$[70]$} \\
\hline & $\begin{array}{c}\text { Trichilia havanensis } \\
\text { Meliacea }\end{array}$ & seeds & $\begin{array}{l}\text { Seed powder (15\% in artificial diet: } 100 \% \\
\text { LM, } 24 \text { days) }\end{array}$ & {$[70]$} \\
\hline
\end{tabular}

\subsection{Tenebrio molitor and Trichoplusia ni}

Sterols 15 and 16 (Figure 1) from M. geometrizans (Cactaceae) and their combination (6:4) exhibited a high toxicity against the last-instar larvae of T. molitor, the yellow mealworm, causing acute toxicities with 5,3 , and $0 \%$ survival at $100 \mathrm{ppm}$, respectively. Interestingly, 15, 16, and their combination induced shortened T. molitor pupation and emergence, and many of the pupae died (Table 17) [24].

Only one report described assays against the cabbage looper $T . n i$, where volatile organic compounds from $A$. indica stems promoted significant neonatal and larval mortality ( 24 and $77 \%$, respectively) at $1 \mathrm{~g}$ doses and an $\mathrm{LD}_{50}$ of $5.6 \mathrm{~g}$ after 7 days (Table 17) [71].

Table 17. Plant extracts and metabolites from Mexican flora with activity on Tenebrio molitor and Trichoplusia ni.

\begin{tabular}{|c|c|c|c|c|}
\hline Insect & Species/Family & Plant Part & Extract/Compound (Toxicity) & Ref. \\
\hline Tenebrio molitor & $\begin{array}{l}\text { Myrtillocactus } \\
\text { geometrizans * } \\
\text { Cactaceae }\end{array}$ & Whole plant & $\begin{array}{c}\text { Macdougallin (15) (100 ppm: 5\% survival) } \\
\text { Peniocerol (16) (100 ppm: 3\% survival) } \\
\text { mixture (6:4) } \mathbf{1 5}+\mathbf{1 6} \text { (100 ppm: 0\% } \\
\text { survival) }\end{array}$ & {$[24]$} \\
\hline Trichoplusia ni & $\begin{array}{c}\text { Azadirachta indica } \\
\text { Meliacea }\end{array}$ & Leaves & $\begin{array}{l}\text { Volatile compounds released }(1 \text { and } 10 \mathrm{~g}: \\
24 \% \text { and } 63 \% \text { neonate mortality; } 77 \% \text { and } \\
\left.79 \% \text { larval mortality; } L_{50}=5.6 \mathrm{~g}, 7 \text { days }\right)\end{array}$ & [71] \\
\hline
\end{tabular}

* Endemic; $\mathrm{LD}_{50}$ : Median Lethal Dose.

\subsection{Trialeurodes vaporariorum}

In reviewing investigations on the effectiveness of Mexican plant products against the greenhouse whitefly, the species Arundo donax, Petiveria alliacea, Phytolacca icosandra, Piper auritum, Raphanus raphanistrum, and Tagetes filifolia were compiled.

\subsubsection{EOs}

Native populations of T. filifola in Mexico contain high proportions of anethole, a phenylpropene present in the EOs from the plant. Therefore, the EOs from the flowers, leaves, and whole plants of T. filifolia were tested together with a commercial standard of trans-anethole (70) against T. vaporariorum. The lowest $\mathrm{LC}_{50}$ value was observed using 70 (Figure 10), which produced an $\mathrm{LC}_{50}$ value of $1.74 \mathrm{mg} / \mathrm{mL}$ and a median oviposition inhibition concentration $\left(\mathrm{IOC}_{50}\right)$ of $1.55 \mathrm{mg} / \mathrm{mL}$, followed by the floral oil $\left(\mathrm{LC}_{50}=6.59 \mathrm{mg} / \mathrm{mL}\right)$, the foliar oil $\left(\mathrm{LC}_{50}=10.29 \mathrm{mg} / \mathrm{mL}\right)$, and the whole plant oil $\left(\mathrm{LC}_{50}=9.99 \mathrm{mg} / \mathrm{mL}\right)$. Another parameter measured was the median repellent concentration $\left(\mathrm{RC}_{50}\right)$, 
with the floral oil being the most effective with an $\mathrm{RC}_{50}$ value of $0.13 \mathrm{mg} / \mathrm{mL}$ against T. vaporariorum. The second instar of the nymphal stage of T. vaporariorum was noticeably sensitive to foliar oil (Table 18) [72].

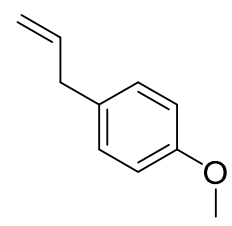

70

Figure 10. Metabolites active against Sitophilus zeamais.

Table 18. Plant extracts from Mexican flora with activity on Trialeurodes vaporariorum.

\begin{tabular}{|c|c|c|c|}
\hline Species/Family & Plant Part & Extract (Toxicity) & Ref. \\
\hline Tagetes filifolia Asteraceae & $\begin{array}{l}\text { Flower } \\
\text { Leaves } \\
\text { Whole } \\
\text { plant }\end{array}$ & $\begin{array}{l}\text { Flower }\left(\mathrm{RC}_{50}=0.13 \mathrm{mg} / \mathrm{mL} ; \mathrm{LC}_{50}=6.59 \mathrm{mg} / \mathrm{mL}, 24 \mathrm{~h} ; \mathrm{OIC}_{50} \text { : }\right. \\
\quad 8.43 \mathrm{mg} / \mathrm{mL} \text {, adults }) \\
\text { Leaves }\left(0.23 \mathrm{mg} / \mathrm{mL} ; \mathrm{LC}_{50}=10.29 \mathrm{mg} / \mathrm{mL}, 24 \mathrm{~h} ; \mathrm{OIC}_{50}: 3.88\right. \\
\mathrm{mg} / \mathrm{mL} \text {, adults }) \\
\text { Whole plant }\left(\mathrm{RC}_{50}=0.24 \mathrm{mg} / \mathrm{mL} ; \mathrm{LC}_{50}=9.9 \mathrm{mg} / \mathrm{mL}, 24 \mathrm{~h} ;\right. \\
\left.\quad \mathrm{OIC}_{50}: 3.56 \mathrm{mg} / \mathrm{mL} \text {, adults }\right) \\
\text { trans-anethole }(70) \text { commercial standard }\left(\mathrm{RC} \mathrm{C}_{50}=0.45 \mathrm{mg} / \mathrm{mL} ;\right. \\
\left.\mathrm{LC}_{50}=1.74 \mathrm{mg} / \mathrm{mL}, 24 \mathrm{~h} ; \mathrm{OIC}_{50}: 1.55 \mathrm{mg} / \mathrm{mL} \text {, adults }\right)\end{array}$ & {$[72]$} \\
\hline Piper auritum Piperaceae & $\begin{array}{l}\text { Leaves } \\
\text { stems }\end{array}$ & $\begin{array}{c}\text { Ethanol }\left(\mathrm{LC}_{50}=116 \mathrm{mg} / \mathrm{mL} \text { on adult, } 24 \mathrm{~h}\right) \\
\text { Acetone }\left(\mathrm{IOC}_{50}=89.1 \mathrm{mg} / \mathrm{mL} \text { on adult, } 24 \mathrm{~h}\right)\end{array}$ & {$[73]$} \\
\hline $\begin{array}{c}\text { Raphanus raphanistrum } \\
\text { Brassicaceae }\end{array}$ & Leaves & $\begin{array}{c}\text { Water }\left(\mathrm{IOC}_{50}=77.3 \mathrm{mg} / \mathrm{mL}, \text { on adult, } 24 \mathrm{~h}\right) \\
\text { Ethanol }\left(\mathrm{LC}_{50}=185.2 \mathrm{mg} / \mathrm{mL}, \text { on adult, } 24 \mathrm{~h}\right)\end{array}$ & [73] \\
\hline $\begin{array}{c}\text { Petiveria alliacea } \\
\text { Petiveriaceae }\end{array}$ & $\begin{array}{l}\text { Aerial } \\
\text { part }\end{array}$ & $\begin{array}{c}\text { Laboratory assays: } \\
\text { Aqueous }\left(\mathrm{LC}_{50}=4.6 \%\right) \\
\text { methanol }\left(\mathrm{LC}_{50}=1.1 \%\right), \\
\text { dichloromethane }\left(\mathrm{LC}_{50}=0.3 \%\right), \\
\text { In greenhouse (tomato) } \\
\text { aqueous }\left(\mathrm{LC}_{50}=16.6 \%\right) \\
\text { methanol }\left(\mathrm{LC}_{50}=13.3 \%\right) \\
\text { dichloromethane }\left(\mathrm{LC}_{50}=3.5 \%\right)\end{array}$ & [74] \\
\hline Arundo donax Poaceae & Roots & $\begin{array}{c}\text { Aqueous (non-active) } \\
\text { Methanol }\left(\mathrm{LC}_{50}=0.57 \% \text { and } 34.79 \% w / v \text {, in vitro and }\right. \\
\text { greenhouse } \mathrm{RC}_{50}=\text {, respectively) }\end{array}$ & [75] \\
\hline $\begin{array}{l}\text { Phytolacca icosandra } \\
\text { Phytolaccaceae }\end{array}$ & $\begin{array}{l}\text { Leaves } \\
\text { stems }\end{array}$ & $\begin{array}{c}\text { Aqueous (non-active) } \\
\text { Methanol }\left(\mathrm{LC}_{50}=0.34 \% \text { and } 36.47 \% \mathrm{w} / \mathrm{v} \text {, in vitro and }\right. \\
\text { greenhouse, respectively) } \\
\text { Qualitative analysis: Terpenoids and saponins }\end{array}$ & {$[75]$} \\
\hline
\end{tabular}

$\mathrm{IOC}_{50}$ : Median Inhibition of Oviposition Concentration; $\mathrm{LC}_{50}=$ Median Lethal Concentration; $\mathrm{RC}_{50}=\mathrm{Median}$ Repellent Concentration.

\subsubsection{Plant Extracts}

Mendoza-García [73] reported that an ethanolic extract of $P$. auritum was the most toxic extract $\left(\mathrm{LC}_{50}=116 \mathrm{mg} / \mathrm{mL}\right)$ tested against $T$. vaporariorum and that an aqueous extract of $R$. raphanistrum effectively inhibited oviposition $\left(\mathrm{IOC}_{50}=77.3 \mathrm{mg} / \mathrm{mL}\right)$ against the greenhouse whitefly.

Evaluations of extracts applied to tomato crops under greenhouse conditions were reported to control T. vaporariorum. In one study, aqueous, methanol, and dichloromethane extracts from P. alliacea leaves showed remarkable $\mathrm{LC}_{50}$ values of $16.6,13.3$, and $3.5 \%$, respectively [74]. In contrast, methanolic extracts from $A$. donax and P. icosandra exhibited slightly higher target $\mathrm{LC}_{50}$ values of 34.79 and $36.47 \%$, respectively, under greenhouse conditions (Table 18) [75]. 


\subsection{Zabrotes subfasciatus}

The species L. palmeri and Senecio salignus exhibited effective activities against Z. subfasciatus, the main pest of common beans (Phaseolus vulgaris). A $0.07 \%$ solution of a root powder of the Asteraceae species $S$. salignus exerted lethal toxicity by contact against bean weevil adults after five days. When the concentration was increased, fewer days were required to control the pest, with a $0.07 \%$ solution producing $\mathrm{LC}_{50}$ values of $0.03 \%$ and $0.08 \%$ after 3 days and median lethal times of 1.21 and 3.20 days observed for male and females, respectively. Therefore, males were more sensitive than females. In addition, the authors determined the optimal size of the root powder that should be used $(<0.25 \mathrm{~mm}$ particles $)$ [76].

EOs

EOs obtained from leaves of L. palmeri collected in the localities of Puerto de Oregano (PO) and Alamo (Al) exhibited lethal and ovicidal activities against Z. subfasciatus at $1.35 \mu \mathrm{L} / \mathrm{g}$, with two months of persistence. EOs from leaves collected in PO was slightly more lethal than EOs obtained from leaves collected in Al. A comparison of the components of the two EOs revealed a number of differences, with carvacrol $(22,37.35 \%)$, thymol $(21,24.56 \%)$, and $p$-cimene $(\mathbf{6 4}, 15.62 \%)$ being abundant in EO from PO, whereas 64 (33.7\%) and 22 (18.32\%) were abundant in EOs from Al (Table 19) [77].

Table 19. Plant extracts from Mexican flora with insecticidal activity against Zabrotes subfasciatus.

\begin{tabular}{|c|c|c|c|}
\hline Species/Family & Plant Part & Extract (Toxicity) & Ref. \\
\hline $\begin{array}{l}\text { Senecio salignus } \\
\text { Asteraceae }\end{array}$ & Roots & $\begin{array}{l}\text { Powder (male: } \mathrm{LC}_{50}=0.03 \%, 3-6 \text { days; } \mathrm{LT}_{50}=1.31 \text { days) } \\
\text { (female: } 0.08 \% 3-6 \text { days; } \mathrm{LT}_{50}=3.2 \text { days) }\end{array}$ & [76] \\
\hline $\begin{array}{l}\text { Lippia palmeri* } \\
\text { Verbenaceae }\end{array}$ & Leaves & $\begin{array}{c}\text { EOs Puerto del oregano }\left(\mathrm{LC}_{50}=1.35 \mu \mathrm{L} / \mathrm{g} \text { mortality, } 48\right), 22 \\
(37.35 \%), 21(24.56 \%), \mathbf{6 4}(15.62 \%) \\
\text { Alamos }\left(\mathrm{LC}_{50}=1.35 \mu \mathrm{L} / \mathrm{g} \text { mortality, } 48\right), \mathbf{6 4}(33.70 \%), \mathbf{2 2} \\
(18.32 \%)\end{array}$ & [77] \\
\hline
\end{tabular}

* Endemic; $\mathrm{LC}_{50}$ : Median Lethal Concentration; $\mathrm{LT}_{50}$ : Median Lethal Time.

\section{Nematicidal Compounds and Plant Extracts}

To date, very few bioprospecting studies have been performed to identify plants with nematicide effects. In this review, we identified reports describing 37 plant species with toxic activities towards plant and animal nematode parasites. These plant species belong to 21 botanical families, with those of the family Fabaceae $(41 \%)$ being predominant. A total of 18 secondary metabolites were identified as active principles or presenting an active fraction against at least one of the parasitic nematodes tested in the reviewed studies, including terpenes (71-82), flavonoids $(44,69,83$, and 86), a pehnylpropaoid (84), and a coumarin (85). These metabolites were obtained from C. anuum, Gliricidia sepium, Leucaena leucocephala, Microsechium helleri, Sicyos bulbosus, and T. graveolens.

\subsection{Plant Extracts Effective against Parasitic Plant Nematodes}

Although data on the subject is scarce, we focused on compiling reports on plants that have toxic effects on phytonematodes Meloidogyne incognita, Meloidogyne javanica, and Nacobbus aberrans. A total of twelve metabolites from M. helleri, S. bulbosus, and C. annuum have been purified and identified as active principles against plant parasite nematodes.

\subsubsection{Meloidogyne javanica}

Seven saponins isolated from S. bulbosus, namely, tacacoside B3 (71) and C (72),16-OH tacacoside B3 (73), durantanin III (74), heteropappus saponin 7 rhamnoside (75), and heteropappus saponin 5 and 7 (76-77), were the active compounds responsible for the nematicidal effect against M. javanica $\mathrm{J}_{2}$ (73.8-100\% mortality at $0.5 \mu \mathrm{g} / \mu \mathrm{L})$. Highly similar compounds, such as amole F-G $(78,79)$ and $16-\mathrm{OH}$ amole F-G $(\mathbf{8 0}, \mathbf{8 1})$, were isolated from $M$. helleri and caused lower $(<8 \%) \mathrm{J}_{2}$ immobility at the $0.5 \mu \mathrm{g} / \mu \mathrm{L}$ 
dose [78]. In addition, the hexane extract from the leaves of $L$. graveolens caused significant mortality against $M$. javanica $\mathrm{J}_{2}$ with an $\mathrm{LC}_{50}$ of $0.672 \mathrm{mg} / \mathrm{mL}$ (Table 20, Figure 11). [27].

Table 20. Phytonematicidal metabolites and plant extracts from Mexican flora.

\begin{tabular}{|c|c|c|c|c|}
\hline Nematode & Species/Family & Plant Part & Compound/Extract (Toxicity) & Ref. \\
\hline \multirow[t]{3}{*}{$\begin{array}{c}\text { Meloidogyne } \\
\text { javanica }\end{array}$} & $\begin{array}{l}\text { Lippia graveolens } \\
\text { Verbenaceae }\end{array}$ & Leaves & $\begin{array}{c}\text { Hexane }\left(\mathrm{LC}_{50}=0.672 \mathrm{mg} / \mathrm{mL}\right) \\
21(70.6 \%), 22(22.8 \%)\end{array}$ & [27] \\
\hline & $\begin{array}{l}\text { Sicyos bulbosus * } \\
\text { Cucurbitaceae }\end{array}$ & Roots & $\begin{array}{c}\text { Tacacoside B3 (71) }\left(0.5 \mu \mathrm{g} / \mu \mathrm{L}: 93 \% \mathrm{~J}_{2} \mathrm{I}\right) \\
\text { tacacoside C (72) }\left(0.5 \mu \mathrm{g} / \mu \mathrm{L}: 97 \% \mathrm{~J}_{2} \mathrm{I}\right) \\
\text { 16-OH-tacacoside B3 }(73)\left(0.5 \mu \mathrm{g} / \mu \mathrm{L}: 100 \% \mathrm{~J}_{2}\right. \\
\text { I), durantanin III (74) }\left(0.5 \mu \mathrm{g} / \mu \mathrm{L}: 74 \% \mathrm{~J}_{2} \mathrm{I}\right) \\
\text { heteropappussaponin } 7 \text { rhamnoside }(75)(0.5 \\
\left.\mu \mathrm{g} / \mu \mathrm{L}: 80 \% \mathrm{~J}_{2} \mathrm{I}\right), \text { heteropappussaponin } 5 \text { (76) } \\
\left(0.5 \mu \mathrm{g} / \mu \mathrm{L}: 91 \% \mathrm{~J}_{2} \mathrm{I}\right) \\
\text { heteropappussaponin } 7(77)\left(0.5 \mu \mathrm{g} / \mu \mathrm{L}: 93 \% \mathrm{~J}_{2}\right. \\
\mathrm{I})\end{array}$ & [78] \\
\hline & $\begin{array}{l}\text { Microsechium helleri } \\
\quad \text { *Cucurbitaceae }\end{array}$ & Roots & $\begin{array}{c}\text { Amole F (78) }\left(0.5 \mu \mathrm{g} / \mu \mathrm{L}: 4.78 \% \mathrm{~J}_{2} \mathrm{I}\right) \\
\text { amole G (79) }\left(0.5 \mu \mathrm{g} / \mu \mathrm{L}: 7.83 \% \mathrm{~J}_{2} \mathrm{I}\right) \\
\text { 16-OH-amole F (80) }\left(0.5 \mu \mathrm{g} / \mu \mathrm{L}: 6.52 \% \mathrm{~J}_{2} \mathrm{I}\right) \\
\left.\text { 16-OH-amole G (81) } 0.5 \mu \mathrm{g} / \mu \mathrm{L}: 6.34 \% \mathrm{~J}_{2} \mathrm{I}\right)\end{array}$ & [78] \\
\hline $\begin{array}{l}\text { Nacobbus } \\
\text { aberrans }\end{array}$ & $\begin{array}{l}\text { Capsicum annuиm } \\
\text { Solanaceae }\end{array}$ & Roots & Capsidiol (82) (1 $\left.\mu \mathrm{g} / \mathrm{mL}:>80 \% \mathrm{~J}_{2} \mathrm{I}, 72 \mathrm{~h}\right)$ & [79] \\
\hline \multirow[t]{3}{*}{$\begin{array}{l}\text { Meloidogyne } \\
\text { incognita }\end{array}$} & $\begin{array}{l}\text { Calea urticifolia } \\
\text { Asteraceae }\end{array}$ & Roots & $\begin{array}{l}\text { Ethanol (250 ppm: } 80 \% \text { larval mortality, } 72 \mathrm{~h}) \\
\text { In greenhouse: } \\
\text { Water (50\% w/v: } 72 \% \text { decrease eggs formation; } \\
50 \% \text { galling reduction) }\end{array}$ & [80] \\
\hline & $\begin{array}{l}\text { Eugenia winzerlingii } \\
{ }^{*} \text { Myrtaceae }\end{array}$ & Leaves & Ethanol $\left(\mathrm{ED}_{50}=133.4 \mathrm{ppm}\right)$ & [81] \\
\hline & $\begin{array}{l}\text { Tephrosia cinerea } \\
\text { Fabaceae }\end{array}$ & Stem & Ethanol (250 ppm: 85\% larval mortality, $72 \mathrm{~h}$ ) & [81] \\
\hline
\end{tabular}

* Endemic; $\mathrm{ED}_{50}$ : Median Effective Dose; I: Immobility; $\mathrm{LC}_{50}$ : Median Lethal Concentration.

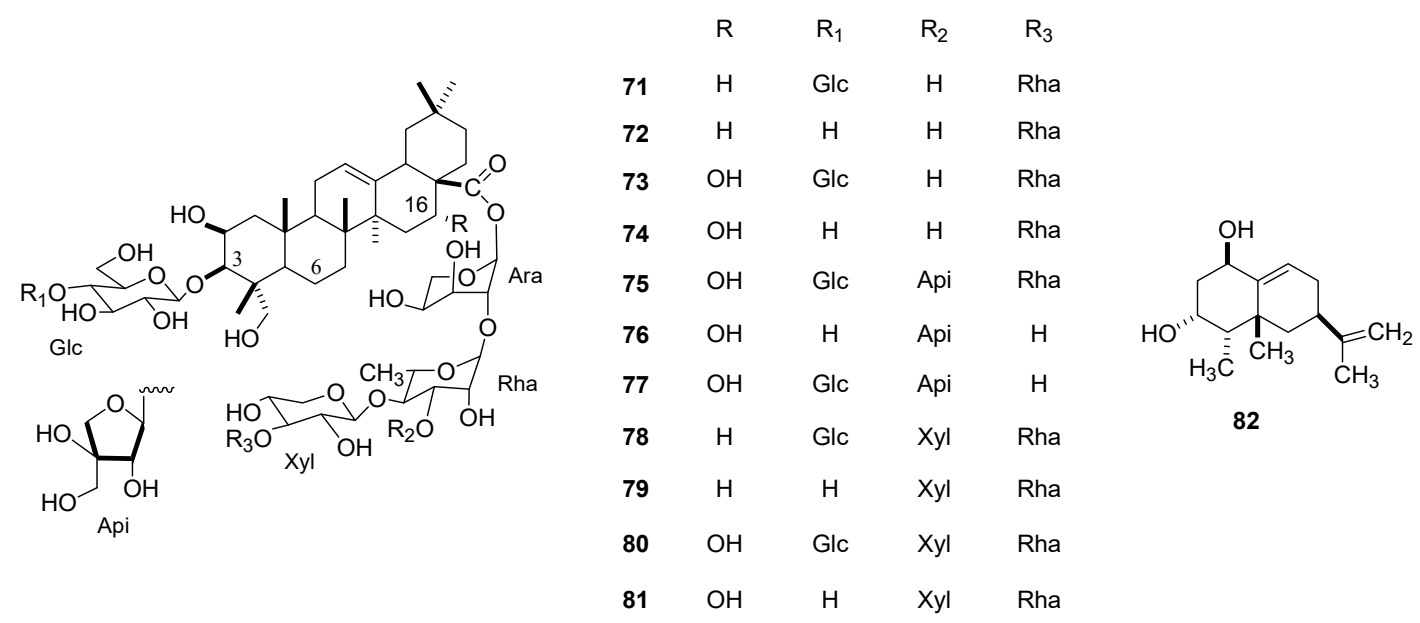

Figure 11. Metabolites effective against Meloidogyne javanica and Nacobbus aberrans.

\subsubsection{Nacobbus aberrans}

The capsidiol (82) produced by C. annuum (Solanaceae) was reported to affect $N$. aberrans (Table 19). Pure capsidiol caused an $80 \%$ immobility in the $\mathrm{J}_{2}$ of $N$. aberrans after exposure for $72 \mathrm{~h}$ at a concentration of $1 \mu \mathrm{g} / \mathrm{mL}$ and caused a nematostatic effect (Table 20, Figure 11) [79]. 


\subsubsection{Meloidogyne incognita}

Plant extracts from Calea urticifolia, E. winzerlingii, and Tephrosia cinerea were shown to have lethal activities against $M$. incognita (Table 20). An aqueous extract from the roots of $C$. urticifolia was tested on second-stage $M$. incognita juveniles under greenhouse conditions. The results showed that $50 \%(w / v)$ of the C. urticifolia root extract effectively reduced gall formation (50\%) and the number of eggs (72\% reduction) on tomato seedlings that had been inoculated with 1000 eggs and 130 M. incognita $\mathrm{J}_{2}$ [80]. Ethanol extracts from the roots of C. urticifolia, the stems of T. cinerea, and the leaves of E. winzerlingii produced immobility in $M$. incognita $\mathrm{J}_{2}(>80 \%)$ when applied at $250 \mathrm{ppm}$. Finally, the ethanol extract from $E$. winzerlingii leaves was very active against $M$. incognita and had the lowest $\mathrm{LC}_{50}(133.4 \mathrm{ppm})$ of the tested extracts [81].

\subsection{Plant Extracts with Activity against Parasitic Animal Nematodes}

To date, 27 plant species have been identified with an effect against animal nematodes, 12 of which belong to the family Fabaceae (43\%). The relevant studies primarily focused on the control of Haemonchus contortus (93\%): one study investigated Haemonchus placei, and three investigated Trichostrongylus colubriformis, zooparasites of sheep. In addition, three studies focused on Cooperia puntacta and Cyatostomin sp., zooparasites of grazing cattle and horses, respectively, and one focused on Ascaridia galli, a bird parasite. Herein, the active plant extracts are included, as well as some fractions or subfractions, with the predominant compounds described by the authors. Only five natural compounds were reported to have an anthelmintic activity against animal nematodes, two of which were purified and identified from plant species and the remaining two as enriched fractions, with compound rutin (35) assayed as a commercial standard.

\subsubsection{Ascaridia galli}

Only one study investigated the effect of metabolites from T. graveolens (Amaranthaceae) against A. galli. Flavonoid 69 (Figure 9) was the active ingredient isolated from the aerial parts of T. graveolens, and it had an $\mathrm{LC}_{50}$ of $623.5 \mu \mathrm{g} / \mathrm{mL}$ against $A$. galli (Table 21) [69].

Table 21. Nematicidal metabolites and plant extracts from Mexican plants with activity on Ascaridia galli, Cooperia puntacta, and Cyathostomin sp.

\begin{tabular}{|c|c|c|c|c|}
\hline Nematode & Species/Family & Plant Part & Compound/Extract (Toxicity) & Ref \\
\hline Ascaridia galli & $\begin{array}{l}\text { Teloxys graveolens } \\
\text { Chenopodiaceae }\end{array}$ & Aerial part & Pinocembrine (69) $\left(\mathrm{LC}_{50}=623.49 \mu \mathrm{g} / \mathrm{mL}\right)$ & [69] \\
\hline \multirow[t]{3}{*}{$\begin{array}{l}\text { Cooperia } \\
\text { punctata }\end{array}$} & $\begin{array}{l}\text { Leucaena } \\
\text { leucocephala } \\
\text { Fabaceae }\end{array}$ & Fresh Leaves & $\begin{array}{c}\text { Water }\left(\mathrm{LC}_{50}=7.93 \mathrm{mg} / \mathrm{mL} \text { EHI }\right) \\
\text { Fraction LlC1F3 }\left(\mathrm{LC}_{50}=0.06 \mathrm{mg} / \mathrm{mL} \mathrm{EHI}\right) \\
\text { Quercetin }(83,82.21 \%), \text { caffeic acid }(\mathbf{8 4} \\
13.42 \%)\end{array}$ & $\begin{array}{l}{[82,} \\
83]\end{array}$ \\
\hline & $\begin{array}{l}\text { Gliricidia sepium } \\
\text { Fabaceae }\end{array}$ & Fresh Leaves & $\begin{array}{c}\text { Acetone }\left(\mathrm{LC}_{50}=1.03 \mathrm{mg} / \mathrm{mL} \mathrm{EHI}\right) \\
\text { 2H-Chromen-2-one }(85)\left(\mathrm{EC}_{50}=0.024\right. \\
\mathrm{mg} / \mathrm{mL} \mathrm{EHI})\end{array}$ & [84] \\
\hline & & & $\begin{array}{c}\text { Oxytroside (86) }(2400 \mu \mathrm{g} / \mathrm{mL} \text { inhibited } \\
\text { exsheathment) }\end{array}$ & [85] \\
\hline \multirow[t]{2}{*}{$\begin{array}{l}\text { Cyathostomin } \\
\text { sp. }\end{array}$} & $\begin{array}{c}\text { Diospyros anisandra } \\
\text { Ebenaceae }\end{array}$ & Leaves Bark & $\begin{array}{c}\text { Methanol bark }\left(\mathrm{LC}_{50}=10.28 \mu \mathrm{g} / \mathrm{mL} \text { EHI in }\right. \\
\text { rainy season }) \\
\text { Methanol leaves }\left(\mathrm{LC}_{50}=18.48 \mu \mathrm{g} / \mathrm{mL} \text { EHI }\right. \\
\text { in rainy season })\end{array}$ & [86] \\
\hline & $\begin{array}{l}\text { Petiveria alliacea } \\
\text { Petraceae }\end{array}$ & Stem & $\begin{array}{c}\text { Methanol }\left(\mathrm{LC}_{50}=28.27 \mu \mathrm{g} / \mathrm{mL} \text { EHI in }\right. \\
\text { rainy season) }\end{array}$ & [86] \\
\hline
\end{tabular}

$\mathrm{EC}_{50}$ : Median Effective Concentration; $\mathrm{LC}_{50}$ : Median Lethal Concentration. EHI: Egg Hatching inhibition. 


\subsubsection{Cooperia puntacta}

Plant species with ovicidal activity against C. puntacta included G. sepium and L. leucocephala. These plants were extracted with water, acetone-water 30:70, and acetone solvents, and all of these fractions were tested. For each plant, at least one of the extracts showed ovicidal activity. The most effective were the acetone extract from G. sepium and the aqueous extract from L. leucocephala, which showed significant LC $_{50}$ values of 1.03 and $7.93 \mathrm{mg} / \mathrm{mL}$ on egg hatching inhibition (EHI), respectively. The addition of a tannin inhibitor (polyethylene glycol) in all of the extracts showed that, with the exception of the G. sepium acetone extract, all exhibited enhanced ovicidal effects. Next, an aqueous extract of L. leucocephala was fractionated using chromatographic methods. Among the fractions obtained, the highest ovicidal effect was observed in L1C1F3, with an $\mathrm{LC}_{50}$ value of 0.06 $\mathrm{mg} / \mathrm{mL}$ detected on Cooperia spp. The analytical data indicated that the majority of components in LlC1F3 were quercetin $(83,82.21 \%)$ and caffeic acid $(84,13.42 \%)$ [82,83].

In contrast, the metabolite $2 \mathrm{H}$-chromen-2-one (85) was purified from the acetone extract of G. sepium by bio-guided fractionation. Metabolite 85 had the highest ovicidal effect $\left(\mathrm{EC}_{50}\right.$ of $0.024 \mathrm{mg} / \mathrm{mL}$ ), EHI, and embryonic development against C. puntacta [84]. A second metabolite isolated from the leaves of G. sepium was identified as oxytroside (86) which inhibited the C. punctata exsheathment process at $2400 \mu \mathrm{g} / \mathrm{mL}$ (Table 21, Figure 12) [85].<smiles>O=c1c(O)c(-c2ccc(O)c(O)c2)oc2cc(O)cc(O)c12</smiles>

83<smiles>O=C(O)/C=C/c1ccc(O)c(O)c1</smiles>

84<smiles>O=c1ccc2ccccc2o1</smiles>

85

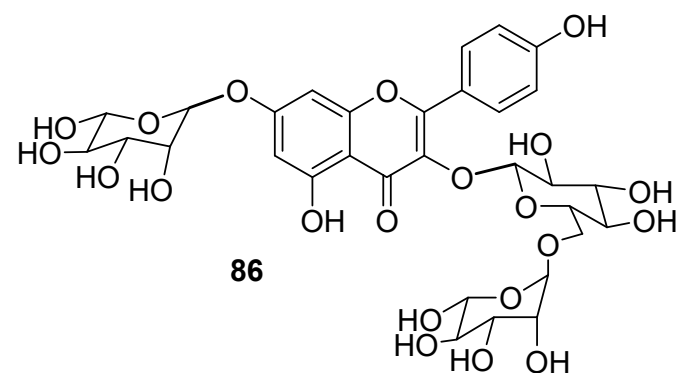

Figure 12. Metabolites from Gliricida sepium and Leucaena leucocephala with activity on Cooperia sp.

\subsubsection{Cyatostomin sp.}

An investigation on the control of the zooparasitic nematode Cyatostomin sp. using plant extracts was recently reported [86]. The authors indicated that methanol extracts from the leaves and bark of Diospyros anisandra (Ebenaceae) and the leaves and stems of P. alliacea, which were collected in the rainy seasons, showed promising activities in controlling the eggs and the development of $\mathrm{L}_{1}$ Cyastotomin sp. larvae. The highest ovicidal activity was produced by the bark extract of $D$. anisandra, followed by the leaf extract, both of which were collected in the rainy season. These extracts presented $\mathrm{LC}_{50}$ values of 10.28 and $18.48 \mu \mathrm{g} / \mathrm{mL}$ on the EHI, respectively, while extracts from P. alliacea exhibited lower lethal activities $\left(\mathrm{LC}_{50} \geq\right.$ of $\left.28.27 \mu \mathrm{g} / \mathrm{mL}\right)$. However, P. alliacea stems, which were also collected in the rainy season, induced the failed eclosion of larvae $(90.7 \%$ at $75 \mu \mathrm{g} / \mathrm{mL})$. The continued study of both plant species was highly recommended (Table 21) [86]. 


\subsubsection{Haemonchus sp.}

Haemonchus placei

A hydroalcoholic extract with significant activity against $H$. placei, was obtained from Caesalpinia coriaria. In this case, the extracts from fruits presented a greater activity than the leaves, with $\mathrm{LC}_{50}$ values of 3.91 and $11.68 \mathrm{mg} / \mathrm{mL}$, respectively [87].

\section{Haemonchus contortus}

In ruminants, $H$. contortus is one of the most important gastrointestinal parasitic nematodes in sheep and goats, as well as H. placei, a hematophagous parasite in bovines. Several plant extracts exhibited promising activities in controlling the larval stage of $H$. contortus in vitro (Table 22. Among these extracts, the dichloromethane extract from Phytolaccca icosandra leaves (Phytolaccaceae) was one of the most active, with an $\mathrm{LD}_{50}$ of $0.90 \mathrm{mg} / \mathrm{mL}$ on larval migration inhibition and an $\mathrm{LD}_{50}$ of $0.28 \mathrm{mg} / \mathrm{mL}$ on egg hatch inhibition (EHI) in H. contortus. Additionally, ethanolic extracts from the same plant caused $>92 \%$ of EHI at a $0.9 \mathrm{mg} / \mathrm{mL}$ in vitro level [88]. In addition, the methanolic extract from Gliricidia sepium (Fabaceae) displayed a good EHI effect, with an $\mathrm{ED}_{50}$ value of $394.96 \mu \mathrm{g} / \mathrm{mL}$ [89]. The hydroalcoholic extract from the leaves of Acacia cochliacantha (Fabaceae) showed total mortality against eggs of $H$. contortus. However, this extract was used at a high concentration $(100 \mathrm{mg} / \mathrm{mL})$, and its organic fraction obtained with ethyl acetate displayed one of the lowest EHI at an $\mathrm{LC}_{50}$ of $0.33 \mathrm{mg} / \mathrm{mL}$. This EHI effect increased ten-fold when it was subfractionated with dichloromethane to produce soluble and precipitate subfractions, with the low $\mathrm{LC}_{50}$ values of 0.06 and $0.04 \mathrm{mg} / \mathrm{mL}$ observed, respectively. The ethyl acetate fraction was enriched with caffeoyl and coumaroyl derivatives [90]. The hydroalcoholic extract from C. coriaria showed a slightly higher effect against $H$. contortus larvae than on $H$. placei. In this case, the extracts from fruits presented $\mathrm{LC}_{50}$ values of 1.63 and $3.98 \mathrm{mg} / \mathrm{mL}$, respectively [87]. In addition, the ethanol extract from the seeds of C. papaya (Caricaceae) induced an EHI of $92 \%$ at $2.5 \mathrm{mg} / \mathrm{mL}$ [91].

The extracts of partially purified tannins obtained from the leaves of Arachis pintoi, L. leucocephala, Guazuma ulmifolia, and Manihot esculenta reduced the migration of the third-stage larvae of $H$. contortus by $69.9-87.4 \%$ at $4.5 \mu \mathrm{g} / \mathrm{mL}$ and $74.2-100 \%$ at $45 \mu \mathrm{g} / \mathrm{mL}$ after $96 \mathrm{~h}$ of exposure. However, an ovicidal effect from these plants was not observed [92]. Alonso-Diaz [93] confirmed the role of tannins in the larvicidal effect of L. leucocephala and other tropical Fabaceae, Acacia pennatula and Lysiloma latisiliquum, with larval migration inhibitions (LMI) of 51-53.6\% at $1200 \mu \mathrm{g} / \mathrm{mL}$ through the use of polyvinyl polypyrrolidine, an inhibitor of tannins. In contrast, Piscidia piscipula was not affected. Vargas-Magaña [94] demonstrated that tannins in a 30\% acetone-water extract $(3600 \mu \mathrm{g} / \mathrm{mL}$ PBS) from the leaves of Laguncularia racemose blocked the eclosion of eggs of $H$. contortus $(50.29 \%)$. Besides, Senegalia gaumeri induced an $\mathrm{EC}_{50}$ of 401.8 and 83.1 $\mu \mathrm{g} / \mathrm{mL}$ of EHI and larval mortality on H. contortus, respectively [95].

In in vitro studies, other investigations reported a lesser effect $(20-40 \mathrm{mg} / \mathrm{mL})$ on H. contortus larval mortality, including the hexane extract from the aerial parts of Prosopis laevigata, an acetone extract from the stem of B. copallifera [96], a hydro-methanolic extract from Larrea tridentata and aqueous extracts from Cydista aequinoctialis, Heliotropium indicum, and Momordica charantia (Table 22) [97,98].

There are seven reports on in vivo experiments that describe the effects of plant extracts. One of these studies included a mixture of extracts from the bulbs of $A$. sativum and the flowers of T. erecta. First, the extracts alone or in combination were tested in vitro. After $72 \mathrm{~h}$, the lowest larval mortality of $H$. contortus $\left(\mathrm{L}_{3}\right)$ occurred at an $\mathrm{LC}_{50}$ of $1.3 \mathrm{mg} / \mathrm{mL}$, which was induced by the mixed extract (Table 22). Subsequently, it was administered in one dose of $100 \mu \mathrm{g} / \mathrm{mL}(40 \mathrm{mg} / \mathrm{mL})$ to gerbils infected with $H$. contortus $\left(\mathrm{L}_{3}\right)$. After 13 days, the nematode in the gastric lumen of both treatment and control animals were counted. The highest larvae population reduction (LPR) was $87.5 \%$, which was induced by the T. erecta and A. sativum mixed extracts. Each extract of these plants alone showed a lower effect in comparison with their combination in both assays, suggesting a synergistic action [99]. Similarly, Zamilpa [100] reported that a combined extract from the aerial parts of Castela tortuosa and 
C. ambrosioides induced a $57.36 \%$ population reduction on $\mathrm{L}_{3} H$. contortus in infected gerbils (Table 23). In contrast, in vitro, the lowest lethal activity was produced by a hexane extract of $C$. ambrosioides $\left(\mathrm{LC}_{50}\right.$ $=1.5 \mathrm{mg} / \mathrm{mL})$ at $72 \mathrm{~h}$ (Table 22). Other hexane extracts administered $(100 \mu \mathrm{g} / \mathrm{mL}$ at $40 \mathrm{mg} / \mathrm{mL})$ to gerbils was from Prosopis laevigata, which reduced parasite population (42.5\%) [101].

Table 22. Plant extracts and metabolites from Mexican flora with in vitro activity against Haemonchus contortus.

\begin{tabular}{|c|c|c|c|}
\hline Species/Family & Plant Part & Extract (Toxicity) & Ref. \\
\hline Caesalpinia coriaria Fabaceae & $\begin{array}{l}\text { Fruits } \\
\text { Leaves }\end{array}$ & $\begin{array}{l}\text { Hydroalcoholic (fruits: } \mathrm{LC}_{50}=1.63 \mathrm{mg} / \mathrm{mL} \text {; leaves: } \mathrm{LC}_{50}= \\
3.98 \mathrm{mg} / \mathrm{mL} \text { on EHI, } 48 \mathrm{~h} \text { ) }\end{array}$ & [87] \\
\hline $\begin{array}{l}\text { Phytolacca icosandra } \\
\text { Phytolaccaceae }\end{array}$ & Leaves & $\begin{array}{c}\text { Dichloromethane }\left(\mathrm{LD}_{50}=0.90 \mathrm{mg} / \mathrm{mL} \text { LMI; } \mathrm{LD}_{50}=0.28\right. \\
\mathrm{mg} / \mathrm{mL} \mathrm{EHI}) \\
\text { Ethanol }(2 \mathrm{mg} / \mathrm{mL}: 55.4 \% \mathrm{LMI} ; 1.8 \mathrm{mg} / \mathrm{mL}: 95 \% \mathrm{EHI})\end{array}$ & [88] \\
\hline Gliricidia sepium Fabaceae & Leaves & Methanol $\left(\mathrm{ED}_{50}=394.96 \mu \mathrm{g} / \mathrm{mL} \mathrm{EHI}\right)$ & [89] \\
\hline Acacia cochliacantha Fabaceae & $\begin{array}{l}\text { Fresh } \\
\text { Leaves }\end{array}$ & $\begin{array}{c}\text { Hydroalcoholic }(100 \mathrm{mg} / \mathrm{mL}: 100 \% \mathrm{EHI}) \\
\text { Ethyl acetate }\left(\mathrm{LC}_{50}=0.33 \mathrm{mg} / \mathrm{mL} \mathrm{EHI}\right) \\
\text { Dichloromethane soluble fraction }\left(\mathrm{LC}_{50}=0.06 \mathrm{mg} / \mathrm{mL} \text { EHI }\right) \\
\text { Dichloromethane precipitate }\left(\mathrm{LC}_{50}=0.04 \mathrm{mg} / \mathrm{mL} \mathrm{EHI}\right)\end{array}$ & {$[90]$} \\
\hline $\begin{array}{l}\text { Carica papaya } \\
\text { Caricaceae }\end{array}$ & Seeds & $\begin{array}{l}\text { Ethanol (2.5 mg/mL: 92\% EHI) } \\
\text { Hydroalcoholic (2.5 mg/mL: 50\% EHI) }\end{array}$ & {$[91]$} \\
\hline Acacia pennatula Fabaceae & Leaves & Tannins (1200 $\mu \mathrm{g} / \mathrm{mL}: 51 \%$ LMI) & [92] \\
\hline $\begin{array}{l}\text { Arachis pintoi } \\
\text { Fabaceae }\end{array}$ & Leaves & Condensed tannins ( $4.5-45 \mu \mathrm{g} / \mathrm{mL}: 76.6-100 \% \mathrm{LM}, 96 \mathrm{~h})$ & [92] \\
\hline Guazuma ulmifolia Malvaceae & Leaves & Condensed tannins ( $4.5-45 \mu \mathrm{g} / \mathrm{mL}: 86.0-99.4 \% \mathrm{LM}, 96 \mathrm{~h})$ & [92] \\
\hline Manihot esculenta Euphorbiaceae & Leaves & Condensed tannins ( $4.5-45 \mu \mathrm{g} / \mathrm{mL}: 69.9-100 \%$, LM, $96 \mathrm{~h})$ & [92] \\
\hline \multirow[t]{2}{*}{ Leucaena leucocephala Fabaceae } & Leaves & Condensed tannins ( $4.5-45 \mu \mathrm{g} / \mathrm{mL}: 71.0-98.4 \% \mathrm{LM}, 96 \mathrm{~h})$ & [92] \\
\hline & Leaves & Tannin $(1200 \mu \mathrm{g} / \mathrm{mL}: 53.6 \% \mathrm{LMI})$ & [93] \\
\hline Lysiloma latisiliquum Fabaceae & $\begin{array}{l}\text { Leaves } \\
\text { Leaves }\end{array}$ & Tannin $(1200 \mu \mathrm{g} / \mathrm{mL}: 49.1 \% \mathrm{LMI})$ & [93] \\
\hline Piscidia piscipula Fabaceae & Leaves & Tannin $(1200 \mu \mathrm{g} / \mathrm{mL}: 63.8 \% \mathrm{LMI})$ & [93] \\
\hline $\begin{array}{l}\text { Laguncularia racemosa } \\
\text { Combretaceae }\end{array}$ & Leaves & $\begin{array}{l}\text { 30\% Acetone-water (3600 } \mu \mathrm{g} / \mathrm{mL}: 50.29 \text { larvae failing } \\
\text { eclosion) }\end{array}$ & [94] \\
\hline Senegalia gaumeri $*$ Fabaceae & Leaves & Acetona-water 70:30 (EC $\left.\mathrm{E}_{50}=401.8 \mathrm{EHI} ; 83.1 \mathrm{LMI}\right)$ & [95] \\
\hline Bursera copallifera * Burseraceae & Stem & Acetone $(20 \mathrm{mg} / \mathrm{mL}: 66 \% \mathrm{LM}, 72 \mathrm{~h})$ & [96] \\
\hline Prosopis laevigata Fabaceae & $\begin{array}{c}\text { Aerial } \\
\text { part }\end{array}$ & Hexane ( $20 \mathrm{mg} / \mathrm{mL}: 86 \% \mathrm{LM}, 72 \mathrm{~h}$ postexposure) & [96] \\
\hline Cydista aequinoctialis Bignonaceae & Leaves & Aqueous (20 mg/mL: 39.57\% LM, $72 \mathrm{~h})$ & [97] \\
\hline $\begin{array}{l}\text { Heliotropium indicum } \\
\text { Boraginaceae }\end{array}$ & Leaves & Aqueous (20 mg/mL: 34.59\% LM, 48 h) & [97] \\
\hline Momordica charantia Cucurbitaceae & $\begin{array}{l}\text { Leaves } \\
\text { Fruits }\end{array}$ & $\begin{array}{l}\text { Aqueous (20 mg/mL: 53.83\% LM, } 72 \mathrm{~h} \text { ) } \\
\text { Aqueous ( } 20 \mathrm{mg} / \mathrm{mL}: 68.13 \% \mathrm{LM}, 72 \mathrm{~h})\end{array}$ & [97] \\
\hline Larrea tridentata Zygophyllaceae & Leaves & $\begin{array}{c}\text { Hydro-methanol } 30 \%\left(\mathrm{EC}_{50}=36 \mathrm{mg} / \mathrm{mL} \text { on exsheathed }\right. \\
\text { larvae, } 24 \mathrm{~h})\end{array}$ & [98] \\
\hline Allium sativum Amaryllidaceae & Bulbs & Hexane $\left(\mathrm{LC}_{50}=3.8 \mathrm{mg} / \mathrm{mL} \mathrm{LM}, 72 \mathrm{~h}\right)$ & [99] \\
\hline $\begin{array}{l}\text { Tagetes erecta } \\
\text { Asteraceae }\end{array}$ & Flowers & Acetone ( $40 \mathrm{mg} / \mathrm{mL}: 36.6 \% \mathrm{LM}, 72 \mathrm{~h})$ & [99] \\
\hline A. sativum-T. erecta & Combined & Combined bulbs and flower $\left(\mathrm{LC}_{50}=1.3 \mathrm{mg} / \mathrm{mL} \mathrm{LM}, 72 \mathrm{~h}\right)$ & [99] \\
\hline Castela tortuosa $*$ Simaroubaceae & $\begin{array}{l}\text { Aerial } \\
\text { part }\end{array}$ & Hexane $\left(\mathrm{LC}_{50}=17.3 \mathrm{mg} / \mathrm{mL}\right.$ EGI, $\left.72 \mathrm{~h}\right)$ & [100] \\
\hline $\begin{array}{l}\text { Chenopodium ambrosioides } \\
\text { Chenopodiaceae }\end{array}$ & $\begin{array}{l}\text { Aerial } \\
\text { part }\end{array}$ & Hexane $\left(\mathrm{LC}_{50}=1.5 \mathrm{mg} / \mathrm{mL}\right.$ EGI, $\left.72 \mathrm{~h}\right)$ & [100] \\
\hline $\begin{array}{l}\text { C. ambrosioides- } \\
\text { C. tortuosa }\end{array}$ & Combined & Hexane $\left(\mathrm{LC}_{50}=6.5 \mathrm{mg} / \mathrm{mL}\right.$ EGI, $\left.72 \mathrm{~h}\right)$ & [100] \\
\hline
\end{tabular}

\footnotetext{
* Endemic; EHI: Egg hatch inhibition; LM: Larval mortality; LMI: larval migration inhibition; LC $_{50}$ : Median Lethal
} Concentration; LD 50 : Median Lethal Dose. 
Table 23. The in vivo evaluations of plant extracts against Haemonchus contortus.

\begin{tabular}{|c|c|c|c|}
\hline Plant Species & Host & Sample (Toxicity) & Ref. \\
\hline $\begin{array}{l}\text { Allium sativum } \\
\text { Amaryllidaceae }\end{array}$ & Gerbils & Oral administration extract (40 mg/mL) (100 $\mu \mathrm{L}: 68.7 \% \mathrm{LPR})$ & [99] \\
\hline Tagetes erecta Asteraceae & Gerbils & Oral administration extract (40 mg/mL) (100 $\mu \mathrm{L}: 53.9 \%$ LPR) & [99] \\
\hline $\begin{array}{l}\text { Allium sativum-Tagetes } \\
\text { erecta } 1: 1 \text { combined }\end{array}$ & Gerbils & $\begin{array}{l}\text { Oral administration combined extract }(40 \mathrm{mg} / \mathrm{mL})(100 \mu \mathrm{L} \text { : } \\
\qquad 87.5 \% \text { LPR })\end{array}$ & [97] \\
\hline Castela tortuosa * & Gerbils & $\begin{array}{l}\text { Hexane extract intraperitoneally administred ( } 40 \mathrm{mg} / \mathrm{kg} \text { BW: } \\
27.15 \% \mathrm{LPR})\end{array}$ & [100] \\
\hline Chenopodium ambrosioides & Gerbils & $\begin{array}{l}\text { Hexane extract }(100 \mu \mathrm{L}) \text { intraperitoneally administred (40 } \\
\mathrm{mg} / \mathrm{kg}: 45.86 \% \mathrm{LPR})\end{array}$ & [100] \\
\hline $\begin{array}{c}\text { Castela tortuosa } \\
\text { Chenopodium ambrosioides } \\
\text { combined }\end{array}$ & Gerbils & $\begin{array}{l}\text { Hexane extract (100 } \mu \mathrm{L}) \text { intraperitoneally administred (40 } \\
\mathrm{mg} / \mathrm{kg} \text { BW: } 57.36 \% \mathrm{LPR})\end{array}$ & [100] \\
\hline Prosopis laevigata & Gerbils & $\begin{array}{l}\text { Hexane extract }(40 \mathrm{mg} / \mathrm{mL}) \text { intraperitoneally administred } \\
(100 \mu \mathrm{L}: 42.5 \% \text { reduced the parasite population })\end{array}$ & [101] \\
\hline \multirow[t]{2}{*}{ Lysiloma acapulcensis * } & Lambs & $\begin{array}{c}\text { Ethyl acetate fraction ( } 25 \mathrm{mg} / \mathrm{kg} \text { BW: } 94.8 \% \text { EHI; } 62.9 \% \text { EPGR) } \\
\text { Dried leaves (5g/kg BW: 50.1\% EPGR) }\end{array}$ & [102] \\
\hline & Sheep & Rutin (36) (10 mg/kg BW: 66.2\% EPGR) & [102] \\
\hline Phytolacca icosandra & Sheep & $\begin{array}{c}\text { Ethanol }(250 \mathrm{mg} / \mathrm{kg}, 2 \text { days: } 72 \% \text { reduction on eggs } / \mathrm{g} \text { of } \\
\text { faeces) }\end{array}$ & [103] \\
\hline $\begin{array}{l}\text { Oxalis tetraphylla } \\
\text { Oxalidaceae }\end{array}$ & Lambs & ( $20 \mathrm{mg} / \mathrm{kg}: 45.6 \%$ reduction in the eggs $/ \mathrm{g}$ of feces) & [104] \\
\hline Acacia cochliacantha & Goats & $\begin{array}{l}\text { Fresh foliage }\left(1.48 \log ^{10} \text { excreted eggs per gram; control } 2.18\right. \\
\left.\qquad \log ^{10} ; 0.6 \mathrm{~kg} / \text { animal weight gained }\right)\end{array}$ & [105] \\
\hline Pithecellobium dulce & Goats & $\begin{array}{l}\text { Fresh foliage }\left(1.18 \log ^{10} \text { excreted eggs per gram; control } 2.18\right. \\
\left.\qquad \log ^{10} ; 2.4 \mathrm{~kg} / \text { animal weight gained }\right)\end{array}$ & [105] \\
\hline
\end{tabular}

An organic ethyl acetate fraction obtained from aqueous extracts of Lysiloma acapulcensis leaves showed a high EHI on $\mathrm{L}_{3}(94.85 \%)$ at $6.25 \mathrm{~g} / \mathrm{mL}$ and a $100 \%$ larval mortality at $50 \mathrm{mg} / \mathrm{mL}$ after $72 \mathrm{~h}$ at the in vitro level. Subsequently, an organic fraction of dry and ground leaves of L. acapulcensis and the flavonol rutin (35) used to treat infected sheep were tested in vivo. The reduction in the excretion of eggs per gram (EPGR) of faeces was recorded, with 35 and the ethyl acetate fraction exhibiting a 66.2 and $62.9 \%$ EPGR at a concentration of 10 and $25 \mathrm{mg} / \mathrm{kg}$ body weight (BW), respectively. The application of the ethyl acetate fraction was more effective than dried leaves $(5 \mathrm{~g} / \mathrm{kg} \mathrm{BW})$, presenting a $62.9 \%$ EPGR. The chromatographic separation of the ethyl acetate fraction revealed the presence of the flavonol myricitrin (87) as a major component, though this enriched fraction was not tested (Figure 13). In this experiment, the larvae of Cooperia curticei, $H$. contortus, and Teladorsagia circumcincta and the eggs of Trichuris sp. from faeces were identified by morphological and morphometric analyses [102]. Another in vivo test was reported with the ethanolic extract from $P$. icosandra leaves which was encapsuled and orally administered to infected goats. Results showed a reduction of $72 \%$ in $\mathrm{H}$. contortus eggs/g of faeces at two doses of $250 \mathrm{mg} / \mathrm{kg}$ BW, on day 11 post-treatment (Table 23). Fatty acids and a ketone were detected in the ethanol extract of $P$. icosandra as major components [103]. 
<smiles>O=c1c(OC2C(O)C(O)C(O)C(O)C2O)c(-c2cc(O)c(O)c(O)c2)oc2cc(O)cc(O)c12</smiles>

Figure 13. Majority component (Myricitrin) of active extract from Lysiloma acapulcensis eaves.

In further studies, a hydroalcoholic extract from Oxalis tetraphylla (Oxalidaceae) leaves was orally applied daily $(20 \mathrm{mg} / \mathrm{kg} \mathrm{BW})$ for eight days to lambs infected with $H$. contortus. The results showed a $45.6 \%$ reduction in the number of eggs/gram of faeces. Flavonol compounds in O. tetraphylla were also detected [104].

Finally, an in vivo test in goats, Creole male kids, experimentally infected with $\mathrm{L}_{3} H$. contortus was reported. In this investigation, kids were fed fresh leaves ( $10 \%$ of the total diet) of A. cochliacantha, G. ulmifolia, and Pithecellobium dulce (Fabaceae) for sixty days. A lower EPG was observed in kids fed with A. cochliacantha and P. dulce, with $1.28 \log ^{10}$ and $1.48 \log ^{10}$, respectively. Moreover, the total body weight in kids noticeably increased with $P$. dulce foliage in the diet, with $0.2 \%$ (control) to $2.4 \% \mathrm{~kg} / \mathrm{animal}$ (treatment) weight gained, which was attributed to the decrease in parasite load [105] (Table 23).

\subsubsection{Trichostongyus colubriformis}

With regards to the nematode T. colubriformis, the extracts from three species of the family Fabaceae (1200 ppm), Acacia pennatula, L. leucocephala, and Lysiloma latisiliquum, reduced the migration of $T$. colubriformis third-stage larvae by $71 \%, 72 \%$, and $56 \%$, respectively (Table 24 ) [106].

Table 24. Extracts from Mexican plants active on Trichostrongylus colubriformis.

\begin{tabular}{cccc}
\hline Species/Family & Plant Part & Extract (Toxicity) & Ref. \\
\hline $\begin{array}{c}\text { Acacia pennatula } \\
\text { Fabaceae }\end{array}$ & Leaves & Tannin $(1200 \mu \mathrm{g} / \mathrm{mL}: 71 \% \mathrm{Lm})$ & {$[106]$} \\
$\begin{array}{c}\text { Leucaena leucocephala } \\
\text { Fabaceae } \\
\begin{array}{c}\text { Lysiloma latisiliquum } \\
\text { Fabaceae }\end{array}\end{array}$ & Leaves & Tannin $(1200 \mu \mathrm{g} / \mathrm{mL}: 72 \% \mathrm{Lm})$ & {$[106]$} \\
\hline
\end{tabular}

Lm: larval migration of third-stage larvae.

\section{Conclusions}

This review demonstrates the relevant pesticidal activity of several native plant species of Mexico, the majority of which were reported at the in vitro level, while some were reported in in vivo assays. Unfortunately, at present, research on bioprospecting plant species from Mexican flora with the aim of developing natural pesticides against insects and nematode pests is still in its early stages. To date, only 114 species of Mexican plants with biological activity against insects or nematode pests have been reported, most of which belong to the Asteraceae (20\%), Fabaceae (15\%), and Lamiaceae (11\%) families (Figure 14). The investigations on the activities of these plants have primarily focused on evaluating the biological activity of raw vegetable extracts or their enriched fractions, and less than $35 \%$ have led to the purification, identification, and evaluation of the active compounds. Among the most common metabolites with activity detected against some of the tested targets are terpenes (58\%), followed by phenols and flavonoids. A mixture of extracts or their pure compounds provides a strategy in the search for natural and safer pesticides. Despite these limitations, species with a high potential for effectiveness were identified for further study in the development of biotechnological products. 

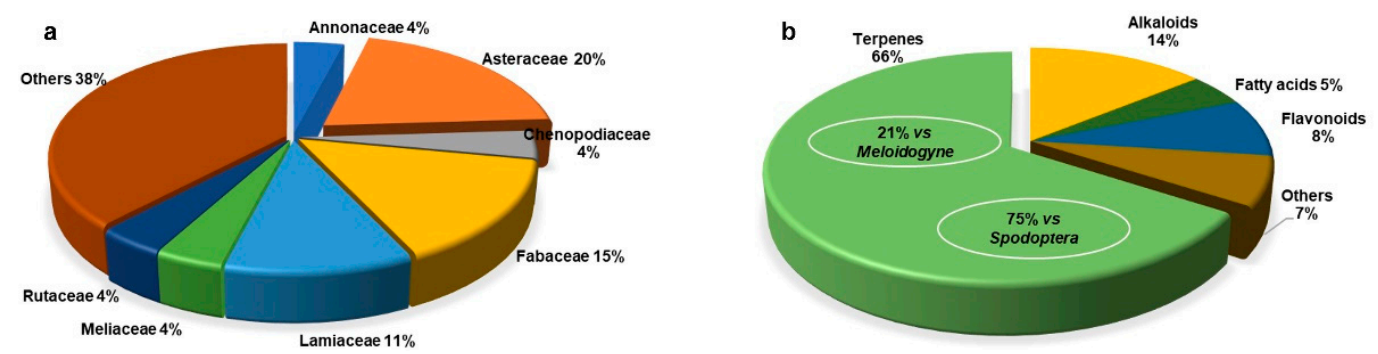

Figure 14. The percentage of (a) plant families explored and (b) types of metabolites isolated from native plants of México that are active on some parasitic pest.

Evaluations of promising plant extracts in the field are needed to identify appropriate formulations. Therefore, the use of an adequate and low-cost extract should be considered during in vitro evaluations. Although botanical pesticides are less persistent in the environment, toxicological studies on beneficial organisms and mammals should still be performed.

The high diversity of plant species in Mexico coupled with the increasing demand and urgency for new natural pesticides makes it extremely important to continue bioprospecting studies in this country. Additional studies will help generate new and alternative natural products that can improve the biological effectiveness, lower residuals, and increase the innocuousness of agricultural products as well as decrease their presence in foods. These studies will contribute to the recognition and dissemination of the importance of propagating plant species for their conservation and sustainable use.

Author Contributions: B.H.-C. and M.G.-A. performed the bibliographical research; B.H.-C. elaborated the tables and drafted the structural formulas; M.G.-A. wrote the manuscript; both authors reviewed and approved the final manuscript.

Funding: This work was supported by the grants 2015-01-266 (Problemas Nacionales) and 2016-1-277609 (Sagarpa), Conacyt, México.

Conflicts of Interest: The authors declare no conflict of interest.

\section{References}

1. Czaja, K.; Góralczyk, K.; Struciński, P.; Hernik, A.; Korczn, W.; Minorczyk, M.; Lyczewska, M.; Ludwicki, J.K. Biopesticides-towards increased consumer safety in the European Union. Pest. Manag. Sci. 2015, 71, 3-6. [CrossRef] [PubMed]

2. Cantrell, C.L.; Dayan, F.E.; Duke, S.O. Natural products as sources for new pesticides. J. Nat. Prod. 2012, 75, 1231-1242. [CrossRef] [PubMed]

3. Hüter, O.F. Use of natural products in the crop protection industry. Phytochem. Rev. 2011, 10, 185-194. [CrossRef]

4. Georgiev, M.I. From plants to pharmacy shelf. Natural products revival. Phytochem. Rev. 2016, 15, 511-513. [CrossRef]

5. Céspedes, C.L.; Alarcon, J.E.; Aqueveque, P.; Seigler, D.S.; Kubo, I. In the search for new secondary metabolites with biopesticidal properties. Israel. J. Plant. Sci. 2015, 62, 216-228. [CrossRef]

6. Isman, M. Bridging the gap: Moving botanical insecticides from the laboratory to the Farm. Ind. Crops Prod. 2017, 110, 10-11. [CrossRef]

7. Andrés, M.F.; González-Coloma, A.; Sanz, J.; Burillo, J.; Sainz, P. Nematicidal activity of essential oils: A review. Phytochem. Rev. 2012, 11, 371-390. [CrossRef]

8. Spiegler, V.; Liebau, E.; Hensel, A. Medicinal plants extracts and plant-derived polyphenols with anthelmintic activity against intestinal nematodes. Nat. Prod. Rep. 2017, 34, 627-643. [CrossRef] [PubMed]

9. Walia, S.; Saha, S.; Tripathi, V.; Sharma, K.K. Phytochemical biopesticides: Some recent developments. Phytochem. Rev. 2018, 16, 989-1007. [CrossRef]

10. Villaseñor, J.L. Checklist of the native vascular plants of Mexico. Rev. Mex. Biodivers. 2016, 87, 550-902. [CrossRef] 
11. Coronado-Aceves, E.W.; Sánchez-Escalante, J.J.; López-Cervantes, J.; Robles-Zepeda, R.E.; Velázquez, C.; Sánchez-Machado, D.I.; Garibay-Escobar, A. Antimycobacterial activity of medicinal plants used by the Mayo people of Sonora, Mexico. J. Ethnopharmacol. 2016, 190, 106-115. [CrossRef] [PubMed]

12. Alanis Garza, B.A.; López Arroyo, J.; González González, G.; Garza González, E.; Waksman de Torres, N.; Salazar Aranda, R. Anti-fungal and anti-mycobacterial activity of plants of Nuevo Leon, Mexico. Pak. J. Pharma. Sci. 2017, 30, 17-21.

13. Jacobo-Herrera, N.J.; Jacob-Herrera, F.E.; Zentella-Dehesa, A.; Andrade-Cetto, A.; Heinrich, M.; Pérez-Plasencia, C. Medicinal plants used in Mexican traditional medicine for the treatment of colorectal cancer. J. Ethnopharmacol. 2016, 179, 391-402. [CrossRef] [PubMed]

14. Ramirez-Mares, M.V.; Hernandez-Carlos, B. Plant -derived natural products from the American continent for the control of phytopathogenic fungi: A review. J. Glob. Innov. Agric. Soc. Sci. 2015, 3, 96-118. [CrossRef]

15. Céspedes, C.L.; Alarcon, J.; Aqueveque, P.M.; Lobo, T.; Becerra, J.; Balbotin, C.; Avila, J.G.; Kubo, I.; Seigler, D.S. New environmentally-friendly antimicrobials and biocides from Andean and Mexican biodiversity. Environ. Res. 2015, 142, 549-562. [CrossRef] [PubMed]

16. Guzman-Pantoja, L.E.; Lina-Garcia, L.P.; Bustos-Zagal, G.; Hernandez-Velazquez, V.M. Current status: Mexican medicinal plants with insecticidal potential. In Bioactive Compounds in Phytomedicine; Rasooli, I., Ed.; Intech: Rijeka, Croatia, 2012; Volume 1, pp. 39-66. ISBN 978-953-307-805-2.

17. Rosado-Aguilar, J.A.; Arjona-Cambranes, K.; Torres-Acosta, J.F.J.; Rodríguez-Vivas, R.I.; Aguilar-Caballero, A.J. Plant products and secondary metabolites with acaricide activity against ticks. Vet. Parasitol. 2017, 238, 66-76. [CrossRef] [PubMed]

18. Salehi, B.; Valussi, M.; Morais-Braga, M.F.B.; Coutinho, H.D.M.; Leal, A.L.A.B.; Mehdi Sharifi-Rad, M.; Vitalini, S.; Kregiel, D.; Antolak, H.; Marcello Iriti, M.; et al. Tagetes spp. essential oils and other extracts: Chemical characterization and biological activity. Molecules 2018, 23, 2847. [CrossRef] [PubMed]

19. Céspedes, C.L.; Torres, P.; Marın, J.C.; Arciniegas, A.; Romo de Vivar, A.; Pérez-Castorena, A.L.; Aranda, E. Insect growth inhibition by tocotrienols and hydroquinones from Roldana barba-johannis. Phytochemistry 2004, 65, 1963-1975. [CrossRef] [PubMed]

20. Céspedes, C.L.; Martínez-Vázquez, M.; Calderón, J.S.; Salazar, J.R.; Aranda, E. Insect growth regulatory activity of some extracts and compounds from Parthenium argentatum on fall armyworm Spodoptera frugiperda. Z. Naturforsch. 2001, 56, 95-105. [CrossRef]

21. Calderón, J.S.; Céspedes, C.L.; Rosas, R.; Gómez-Garibay, F.; Salazar, J.R.; Lina, L.; Aranda, E.; Kubo, I. Acetylcholinesterase and insect growth activities of Gutierrezia microcephala on fall Army worm Spodoptera frugiperda J.E. Smith. Z. Naturforsch. 2001, 56, 382-394.

22. Céspedes, C.; Calderón, J.S.; Lina, L.; Aranda, E. Growth inhibitory effects on fall armyworm Spodoptera frugiperda of some limonoids isolated from Cedrela spp. (Meliaceae). J. Agric. Food. Chem. 2000, 48, 1903-1908. [CrossRef] [PubMed]

23. Villegas Gómez, C.; Martínez Vázquez, M.; Esquivel, B. Antifeedant activity of anticopalic acid isolated from Vitex hemsleyi. Z. Naturforsch. 2009, 64, 502-508. [CrossRef]

24. Céspedes, C.L.; Salazar, J.R.; Martínez, M.; Aranda, E. Insect growth regulatory effects of some extracts and sterols from Myrtillocactus geometrizans (Cactaceae) against Spodoptera frugiperda and Tenebrio molitor. Phytochemistry 2005, 66, 2481-2493. [CrossRef] [PubMed]

25. Valladares-Cisneros, M.G.; Rios-Gomez, M.Y. Iridoids from Crescentia alata. J. Nat. Prod. 2007, 70, $100-102$. [CrossRef] [PubMed]

26. Valladares-Cisneros, M.G.; Rios-Gomez, M.Y.; Aldana-Llanos, L.; Valdes-Estrada, M.E.; Gutiérrez-Ochoa, M. Biological activity of Crescentia alata (Lamiales: Bignoniaceae) fractions on larvae of Spodoptera frugiperda (Lepidoptera: Noctuidae). Fla. Entomol. 2014, 97, 770-777. [CrossRef]

27. Guevara, P.; Reyna-Segura, J.; Zuñiga-Ruiz, B.; Llanos-Romero, R.E.; Andrés-Yeves, M.F.; Barajas-Guzmán, M.G.; Echeverri, F.; León-Rivera, I. Biocidal effect of a hexane-soluble extract of Lippia graveolens Kunth (Verbenaceae). Bol. Latinoam. Caribe Plant. Med. Aromat. 2018, 17, 342-349.

28. Simmonds, M.S.J.; Blaney, W.M.; Esquivel, B.; Rodriguez-Hann, L. Effect of clerodane-type diterpenoids isolated from Salvia spp. On the feeding behavior of Spodoptera littoralis. Pestic. Sci. 1996, 47, 17-23. [CrossRef]

29. Burgueño-Tapia, E.; González-Coloma, A.; Martín-Benito, D.; Joseph-Nathan, P. Antifeedant and phytotoxic activity of cacalolides and eremophilanolides. Z. Naturforsch. 2007, 62, 362-366. [CrossRef] 
30. Ayil-Gutiérrez, B.A.; Villegas-Mendoza, J.M.; Santes-Hernández, Z.; Paz-González, A.D.; Mireles-Martínez, M.; Rosas-García, N.M.; Rivera, G. Ruta graveolens extracts and metabolites against Spodoptera frugiperda. Nat. Prod. Comm. 2015, 10, 1955-1958.

31. Torres, P.; Avila, J.G.; Romo de Vivar, A.; García, A.M.; Marín, J.C.; Aranda, E.; Céspedes, C.L. Antioxidant and insect growth regulatory activities of stilbenes and extracts from Yucca periculosa. Phytochemistry 2003, 64, 463-473. [CrossRef]

32. Pérez-Gutiérrez, S.; Zavala-Sánchez, M.A.; González-Chávez, M.M.; Cárdenas-Ortega, N.C.; Ramos-López, M.A. Bioactivity of Carica papaya (Caricaceae) against Spodoptera frugiperda (Lepidoptera: Noctuidae). Molecules. 2011, 16, 7502-7509. [CrossRef] [PubMed]

33. Ramos-López, M.A.; González-Chávez, M.M.; Cárdenas-Ortega, N.C.; Zavala-Sánchez, M.A.; Pérez, S. Activity of the main fatty acid components of the hexane leaf extract of Ricinus communis against Spodoptera frugiperda. Afr. J. Biotechnol. 2012, 11, 4274-4278. [CrossRef]

34. Armendariz, J.; Lapuerta, M.; Zavala, F.; García-Zambrano, E.; Ojeda, M.C. Evaluation of eleven genotypes of castoroil plant (Ricinus communis L.) for the production of biodiesel. Ind. Crop Prod. 2015, 77, 484-490. [CrossRef]

35. Franco Archundia, S.L.; Jiménez Pérez, A.; Luna León, C.; Figueroa Brito, R. Efecto tóxico de semillas de cuatro variedades de Carica papaya (Caricaceae) en Spodoptera frugiperda (lepidoptera: Noctuidae). Folia Entomol. Mex. 2006, 45, 171-177.

36. Figueroa Brito, R.; Huerta-de la Peña, A.; Pérez-Moreno, I.; Mancebón, V.S.M.; López-Olguín, J.F. Insecticidal activity of seed extracts of Carica papaya (L.) against the fall armyworm Spodoptera frugiperda (JE Smith) (Lepidoptera: Noctuidae). Interciencia 2011, 36, 752-756.

37. Bermúdez-Torres, K.; Martínez Herrera, J.; Figueroa-Brito, R.; Wink, M.; Legal, L. Activity of quinolizidine alkaloids from three Mexican Lupinus against the lepidopteran crop pest Spodoptera frugiperda. BioControl 2009, 54, 459-466. [CrossRef]

38. De la Torre-Anzúres, J.; Aragón-García, A.; Pérez-Torres, B.C.; López-Olguín, J.F. Actividad Biológica de un extracto de semillas de Trichilia havanensis Jacq. Sobre larvas de Spodoptera exigua (Hübner). Southwest. Entomol. 2017, 42, 1069-1077. [CrossRef]

39. Rodríguez-López, V.; Figueroa-Suarez, M.Z.; Rodríguez, T.; Aranda, E. Insecticidal activity of Vitex mollis. Fitoterapia 2007, 78, 37-39. [CrossRef] [PubMed]

40. Aldana-Llanos, L.; Salinas-Sánchez, D.O.; Valdés-Estrada, M.E.; Gutiérrez-Ochoa, M.; Rodríguez Flores, E.Y.; Navarro-García, V.M. Biological activity of dose extracts of Tagetes erecta L. on Spodoptera frugiperda (J. E. Smith). Southwest. Entomol. 2012, 37, 31-38. [CrossRef]

41. Aldana Llanos, L.; Salinas Sánchez, D.O.; Valdés Estrada, M.E.; Gutiérrez Ochoa, M.; Valladares Cisneros, M.G. Evaluación bioinsecticida de extractos de Bursera copallifera (D.C.) Bullock y Bursera grandifolia (Schledl.) Engl. En gusano cogollero Spodoptera frugiperda J.E. Smith (Lepidoptera: Noctuidae). Polibotánica 2010, 29, 149-158.

42. Cárdenas, R.; Reguera-Serrano, J.J.; Llanos-Romero, E.; Aguirre-Hernández, E.; Herrera-Santoyo, J.; Zuñiga, B.; Rodarte, B.; Alba-Lois, L.; Guevara-Fefer, P. Effects of organic extracts of Bursera copallifera and B. lancifolia leaves in the development of Spodoptera frugiperda. J. Entomol. 2012, 9, 115-122. [CrossRef]

43. Guzmán-Pantoja, L.E.; Guevara-Fefer, P.; Villarreal-Ortega, M.L.; León-Rivera, I.; Aranda-Escobar, E.; Martínez-Peniche, R.A.; Hernández-Velázquez, V.M. Biological activity of Ipomoea pauciflora Martens and Galeotti (Convolvulaceae) extracts and fractions on larvae of Spodoptera frugiperda J. E. Smith (Lepidoptera: Noctuidae). Afr. J. Biotechnol. 2010, 9, 3659-3665. [CrossRef]

44. Zavala-Sánchez, M.A.; Pérez-Gutiérrez, S.P.; Romo-Asunción, D.; Cárdenas-Ortega, N.C.; Ramos López, M.A. Activity of four Salvia species against Spodoptera frugiperda (JE Smith) (Lepidoptera: Noctuidae). Southwest. Entomol. 2013, 38, 67-73. [CrossRef]

45. Vera Curzio, L.G.; Hernández Velázquez, V.M.; León Rivera, I.; Guevara Fefer, P.; Aranda Escobar, E. Biological activity of methanolic extracts of Ipomoea murucoides Roem et Schult on Spodoptera frugiperda J.E. Smith. J. Entomol. 2009, 6, 109-116.

46. Hernández-Morales, A.; Arvizu-Gómez, J.L.; Carranza-Álvarez, C.; Gómez-Luna, B.E.; Alvarado-Sánchez, B.; Ramírez-Chávez, E.; Molina-Torres, J. Larvicidal activity of affinin and its derived amides from Heliopsis longipes A. Gray Blake against Anopheles albimanus and Aedes aegypti. J. Asia-Pac. Entomol. 2015, 18, 227-231. [CrossRef] 
47. García-Mateos, R.; Pérez-Pacheco, R.; Rodríguez-Hernández, C.; Soto-Hernánez, M. Toxicidad de alcaloides de Erythrina americana en larvas de mosquito Culex quinquefasciatus. Rev. Fitotec. Mex. 2004, 27, 297-303.

48. Villa-Ruano, N.; Pacheco-Hernández, Y.; Rubio-Rosas, E.; Lozoya-Gloria, E.; Mosso-González, C.; Ramón-Canul, L.G.; Cruz-Durán, R. Essential oil composition and biological/pharmacological properties of Salmea scandens (L.) DC. Food Control. 2015, 57, 177-184. [CrossRef]

49. Granados-Echegoyen, C.; Pérez-Pacheco, R.; Alonso-Hernández, N.; Vázquez-López, A.; Lagunez-Rivera, L.; Rojas-Olivos, A. Chemical characterization and mosquito larvicidal activity of essential oil from leaves of Persea americana Mill (Lauraceae) against Culex quinquefasciatus (Say). Asian. Pac. J. Trop. Dis. 2015, 5, $463-467$. [CrossRef]

50. Granados-Echegoyen, C.; Pérez-Pacheco, R.; Soto-Hernández, M.; Ruiz-Vega, J.; Lagunez-Rivera, L.; Alonso-Hernández, N.; Gato-Armas, R. Inhibition of the growth and development of mosquito larvae of Culex quinquefasciatus (Diptera: Culicidae) treated with extract from leaves of Pseudocalymma alliaceum (Bignonaceae). Asian. Pac. J. Trop. Med. 2014, 7, 594-601. [CrossRef]

51. Ruiz-Guerrero, R.; Rodríguez-Pérez, M.A.; Norzagaray-Campos, M. Toxicity of Mexican native plant extracts against larvae of Aedes aegypti (Diptera: Culicidae). Asian. Pac. J. Trop. Biomed. 2015, 5, 287-291. [CrossRef]

52. De la Torre Rodríguez, Y.C.; Martínez Estrada, F.R.; Flores Suárez, A.E.; Waksman de Torres, N.; Salazar Aranda, R. Larvicidal and cytotoxic activities of extracts from 11 native plants from northeastern Mexico. J. Med. Entomol. 2013, 50, 310-313. [CrossRef] [PubMed]

53. Martinez-Tomas, S.H.; Pérez-Pacheco, R.; Rodríguez-Hernández, C.; Ramírez-Valverde, G.; Ruiz-Vega, J. Effects of an aqueous extract of Azadirachta indica on the growth of larvae and development of pupae of Culex quinquefasciatus. Afri. J. Biotech. 2009, 8, 4245-4250.

54. González-Esquinca, A.R.; Luna-Cazáres, L.M.; Guzmán, M.A.S.; De la Cruz-Chacón, I.; Laguna-Hernández, G.; Flores-Breceda, S.; Montoya-Gerardo, P. In vitro larvicidal evaluation of Annona muricata L., A, diversifolia Saff. and A. lutescens Saff. extracts against Anastrepha ludens larvae (Diptera: Tephritidae). Interciencia 2012, 37, 284-289.

55. Flores-Estévez, N.; Vasquez-Morales, S.G.; Cano-Medina, T.; Sánchez-Velásquez, L.R.; Noa-Carranza, J.C.; Díaz-Fleischer, F. Insecticidal activity of raw ethanolic extracts from Magnolia dealbata Zucc on a tephritid pest. J. Environ. Sci. Health. B. 2013, 48, 582-586. [CrossRef] [PubMed]

56. Flores-Dávila, M.; González-Villegas, R.; Guerrero-Rodríguez, E.; Mendoza-Villarreal, R.; Cárdenas-Elizondo, A.; Cerna-Chavez, E.; Aguirre-Uribe, L. Insecticidal effect of plant extracts on Bactericera cockerelli (Hemiptera: Psyllidae) nymphs. Southwest. Entomol. 2011, 36, 137-144. [CrossRef]

57. Cruz-Estrada, A.; Gamboa-Angulo, M.; Borges-Argáez, R.; Ruiz-Sánchez, E. Insecticidal effects of plant extracts on immature whitefly Bemisia tabaci Genn. (Hemiptera: Aleyroideae). Electron. J. Biotechnol. 2013, 16, 1-9. [CrossRef]

58. Herbert-Doctor, L.A.; Saavedra-Aguilar, M.; Villarreal, M.L.; Cardoso-Taketa, A.; Vite-Vallejo, O. Insecticidal and nematicidal effects of Agave tequilana juice against Bemisia tabaci and Panagrellus redivivus. Southwest. Entomol. 2016, 41, 27-40. [CrossRef]

59. Castillo-Sánchez, L.E.; Jiménez-Osornio, J.J.; Delgado-Herrera, M.A. The in vitro biological activity of Capsicum chinense Jacq extract against Bemisia tabaci Genn. Rev. Chapingo. Ser. Hortic. 2012, 18, 345-356. [CrossRef]

60. Vite-Vallejo, O.; Barajas-Fernández, M.G.; Saavedra-Aguilar, M.; Cardoso-Taketa, A. Insecticidal Effects of Ethanolic Extracts of Chenopodium ambrosioides, Piper nigrum, Thymus vulgaris, and Origanum vulgare against Bemisia tabaci. Southwest. Entomol. 2018, 43, 303-393. [CrossRef]

61. Ail-Catzim, C.E.; García-López, A.M.; Troncoso-Rojas, R.; González-Rodríguez, R.E.; Sánchez-Segura, Y. Insecticidal and repellent effect of extracts of Pluchea sericea (Nutt.) on adults of Bemisia tabaci (Genn.). Rev. Chapingo Ser. Hortic. 2015, 21, 33-41. [CrossRef]

62. Vázquez-Covarrubias, D.A.; Jiménez-Pérez, A.; Castrejón-Ayala, F.; Figueroa-Brito, R.; Montes Belmont, R. Effects of five species of Chenopodiaceae on the development and reproductive potential of Copitarsia decolora (Lepidoptera: Noctuidae). Fla. Entomol. 2015, 98, 80-85. [CrossRef]

63. Vázquez-García, M.; Garabito-Espinoza, S.; Tabares-Vega, J.; Castillo-Herrera, G. Essential oils from aromatic plant species and insecticidal effects on Dactylopius opuntiae (Cockerell) (Homoptera: Dactylopiidae) in mobile juveniles. Acta Hort. 2010, 894, 215-223. [CrossRef] 
64. Martínez-Evaristo, X.C.; Borboa-Flores, J.; Wong-Corral, F.J.; Cinco-Moroyoqui, F.J.; Del-Toro-Sánchez, C.L.; González-de León, A.; Ortega-Nieblas, M.M.; Cornejo-Ramírez, Y.I.; Osuna-Amarillas, P.S.; Cabral-Torres, F.A. Insecticidal efficacy and repellency of oregano (Lippia palmeri) essential oil for control of Sitophilus zeamais and Prostephanus truncatus in stored maize. Southwest. Entomol. 2015, 40, 713-720. [CrossRef]

65. Reyes-Chilpa, R.; Jiménez-Estrada, M.; Cristóbal-Telésforo, E.; Torres-Colín, L.; Villavicencio, M.A.; Pérez-Escandón, B.E.; Mercado-González, R. Natural insecticides from Hippocratea excelsa and Hippocratea celastroides. Econ. Bot. 2003, 57, 54-64. [CrossRef]

66. Pimienta-Ramírez, L.; García-Rodríguez, Y.M.; Ríos-Ramírez, E.M.; Lindig-Cisneros, R.; Espinoza-García, F.J. Chemical composition and evaluation of the essential oil from Eupatorium glabratum as biopesticide against Sitophilus zeamais and several stored maize fungi. J. Essent. Oil. Res. 2015, 28, 113-120. [CrossRef]

67. Juárez-Flores, B.I.; Jasso-Pineda, Y.; Aguirre-Rivera, J.R.; Jasso- Pineda, I. Efecto de polvos de asteráceas sobre el gorgojo del maíz (Sitophilus zeamais Motsch). Polibotánica 2010, 30, 123-135.

68. Anaya, A.N.; Macías-Rubalcava, M.; Cruz-Ortega, R.; García-Santana, C.; Sánchez-Monterrubio, P.N.; Hernández-Butista, B.E.; Mata, R. Allelochemicals from Stauranthus perforatus, a Rutaceous tree of the Yucatan peninsula, Mexico. Phytochemistry 2005, 66, 487-494. [CrossRef] [PubMed]

69. Camacho, M.D.R.; Sanchez, B.; Quiroz, H.; Contreras, J.L.; Mata, R. Pinocembrine: A bioactive flavanone from Teloxys graveolens. J. Ethnopharmacol. 1991, 31, 383-389. [CrossRef]

70. Valdés-Estrada, M.E.; Aldana-Llanos, L.; Hernández-Reyes, M.C.; Gutiérrez-Ochoa, M.; Figueroa-Brito, R. Toxicidad de polvos vegetales en larvas de Scyphophorus acupunctatus Gyllenhal. Coleoptera: Curculionidae). Southwes. Entomol. 2014, 39, 595-599.

71. Nuñez-Mejía, G.; Valadez-Lira, J.A.; Gomez-Flores, R.; Rodríguez-Padilla, C.; Tamez-Guerra, P. Trichoplusia ni (Lepidoptera: Noctuidae) survival, immune response, and gut bacteria changes after exporure to Azadirachta indica (Sapindales: Meliaceae) volatiles. Fla. Entomol. 2016, 99, 12-20. [CrossRef]

72. Camarillo, G.; Ortega, L.D.; Serrato, M.A.; Rodríguez, C. Biological activity of Tagetes filifolia (Asteraceae) on Trialeurodes vaporariorum (Hemiptera: Aleyrodidae). Rev. Colomb. Entomol. 2009, 35, 177-184.

73. Mendoza-García, E.E.; Ortega-Arenas, L.D.; Pérez-Pacheco, R.; Rodríguez-Hernández, C. Repellency, toxicity, and oviposition inhibition of vegetable extracts against greenhouse whitefly Trialeurodes vaporariorum (Westwood) (Hemiptera: Aleyrodidae). Chilean. J. Agric. Res. 2014, 74, 41-48. [CrossRef]

74. García-Mateos, M.R.; Sánchez, E.E.; Espinosa-Robles, P.; Álvarez-Sánchez, M.E. Toxicity of Petiveria alliacea L. on greenhouse whitefly (Trialeurodes vaporariorum West.). Interciencia 2007, 32, 121-124.

75. Ángeles-Martínez, O.; García-Mateos, M.R.; Rodríguez-Pérez, E.; Sánchez-Álvarez, E.; Soto-Hernández, M. Toxicidad de extractos vegetales para el control de Trialeurodes vaporariorum W. (Homoptera: Aleyrodidae) en laboratorio y en cultivo de tomate en invernadero. J. Agric. Univ. PR. 2011, 95, 117-132.

76. López-Pérez, E.; Rodríguez-Hernández, C.; Ortega-Arenas, L.D.; Garza-García, R. Biological activity of Senecio salignus root against Zabrotes subfasciatus in stored bean. Agrociencia 2007, 41, 95-102.

77. Ortega-Nieblas, M.M.; Robles Burgueño, M.R.; Vázquez-Moreno, L.; Cortez-Mondaca, E.; González-León, A.; Morales-Trejo, A.; González-Rios, H. Efecto tóxico y persistente del aceite esencial del orégano contra Zabrotes subfasciats (Coleoptera: Bruchidae) en frijol almacenado. Southwest. Entomol. 2014, 39, 147-161. [CrossRef]

78. Hernández-Carlos, B.; González-Coloma, A.; Orozco-Valencia, A.U.; Ramírez-Mares, M.V.; Andrés-Yeves, M.F.; Joseph-Nathan, P. Bioactive saponins from Microsechium helleri and Sicyos bulbosus. Phytochemistry 2011, 72, 743-751. [CrossRef] [PubMed]

79. Godinez-Vidal, D.; Soto-Hernández, M.; Rocha Sosa, M.; Lozaya-Gloria, E.; Rojas-Martínez, R.I.; Guevara-Olvera, L.; Zavaleta-Mejía, E. Contenido de capsidiol en raíces de chile CM-334 infectadas por Nacobbus aberrans y su efecto en juveniles del Segundo estadío. Nematropica. 2010, 40, 227-237.

80. Herrera-Parra, E.; Cristóbal-Alejo, J.; Tún-Suárez, J.M.; Gamboa-Angulo, M.M.; Marbán-Mendoza, N. Extractos acuosos de Calea urticifolia para el control de Meloidogyne incognita. Nematropica 2009, 39, 289-296.

81. Cristóbal-Alejo, J.; Tun-Suárez, J.M.; Moguel-Catzin, S.; Marbán-Mendoza, N.; Medina-Baizabal, L.; Simá-Polanco, P.; Peraza-Sánchez, E.R.; Gamboa-Angulo, M.M. In vitro sensitivity of Meloidogyne incognita to extracts from native Yucatecan plants. Nematropica 2006, 36, 89-97.

82. Von Son-de Fernex, E.; Alonso Díaz, M.A.; Mendoza de Gives, P.; Valles de la Mora, B.; Zamilpa, A.; González-Cortasar, M. Actividad ovicida de extractos de cuatro especies de plantas contra el nematodo gastrointestinal Cooperia punctate. Vet. Mex. 2016, 3, 10-25. [CrossRef] 
83. Von Son-de Fernex, E.; Alonso-Díaz, M.A.; Mendoza-de Gives, P.; Valles-de la Mora, B.; Castillo Gallegos, E. Elucidation of Leucaena leucocephala anthelmintic-like phytochemicals and the ultrastructural damage generated to eggs of Cooperia spp. Vet. Parasitol. 2015, 214, 89-95. [CrossRef] [PubMed]

84. Von Son-de Fernex, E.; Alonso-Díaz, M.A.; Valles-de la Mora, B.; Mendoza-de Gives, P.; González-Cortazar, M.; Zamilpa, A. Anthelmintic effect of 2H-chromen-2-one isolated from Gliricidia sepium against Cooperia punctate. Exp. Parasitol. 2017, 178, 1-6. [CrossRef] [PubMed]

85. Von Son-de Fernex, E.; Alonso-Díaz, M.A.; Valles-de la Mora, B.; Mendoza-de Gives, P.; Castillo Gallegos, E.; Zamilpa, A.; González-Cortazar, M. Effect of Gliricidia sepium leaves intake on larval establishment of Cooperia punctata in calves and bio-guided fractionation of bioactive molecules. Vet. Parasitol. 2018, 252, 137-141. [CrossRef] [PubMed]

86. Flota-Burgos, G.J.; Rosado-Aguilar, J.A.; Rodríguez-Vivas, R.I.; Arjona-Cambranes, K.A. Anthelminthic activity of methanol extracts of Diospyros anisandra and Petiveria alliacea on cyathostomin (Nematoda: Cyathostominae) larval development and egg hatching. Vet. Parasitol. 2017, 248, 74-79. [CrossRef] [PubMed]

87. Olmedo-Juarez, A.; Rojo-Rubio, R.; Mendoza-de Gives, P.; Vázquez-Armijo, J.F.; Albarran-Portillo, B.; Garcia-Hernandez, C. Ovicidal effect of the fruit and leaf of Caesalpinia coriaria against Haemonchus contortus and Haemonchus placei. J. Animal Sci. 2017, 95, 15. [CrossRef]

88. Hernández-Villegas, M.M.; Borges-Argáez, R.; Rodriguez-Vivas, R.I.; Torres-Acosta, J.F.J.; Méndez-González, M.; Cáceres-Farfan, M. Ovicidal and larvicidal activity of the crude extracts from Phytolacca icosandra against Haemonchus contortus. Vet. Parasitol. 2011, 179, 100-106. [CrossRef] [PubMed]

89. Pérez-Pérez, C.; Hernández-Villegas, M.M.; de la Cruz-Burelo, P.; Bolio-López, G.I.; Hernández-Bolio, G.I. Efecto antihelmíntico in vitro del extracto metanólico de hojas de Gliricida sepium contra nematodos gastrointestinales en ovinos. Trop. Subtrop. Agroecosyst. 2014, 17, 105-111.

90. Castillo-Mitre, G.F.; Olmedo-Juárez, A.; Rojo-Rubio, R.; González-Cortázar, M.; Mendoza-de Gives, P.; Vázquez-Armijo, J.F.; Hernández-Beteta, E.E.; Reyes-Guerrero, D.E.; López-Arellan, M.E.; Vazquez-Armijo, G.; et al. Caffeoyl and coumaroyl derivatives from Acacia cochliacantha exhibit ovicidal activity against Haemonchus contortus. J. Ethnopharmacol. 2017, 204, 125-131. [CrossRef] [PubMed]

91. Marroquín-Tun, M.A.; Higuera-Piedrahita, R.I.; López-Arellano, M.E.; López-Arellano, R.; Cruz-Cruz, H.A.; Silva-Mendoza, R.; Cuéllar-Ordaz, J.A. Efecto in vitro de los extractos hidroalcohólico y etanólico de semilla de papaya (Carica papaya) en Haemonchus contortus. Ciencia Y Agric. 2018, 15, 53-59. [CrossRef]

92. López, J.; Ibarra, O.F.; Cantó, G.J.; Vásquez, C.G.; Tejada, Z.I.; Shimada, A. In vitro effect of condensed tannins from tropical fodder crops against eggs and larvae of the nematode Haemonchus contortus. J. Food. Agric. Environ. 2005, 3, 191-194.

93. Alonso-Díaz, M.A.; Torres-Acosta, J.F.J.; Sandoval-Castro, C.A.; Aguilar-Caballero, A.J.; Hoste, H. In vitro larval migration and kinetics of exsheathment of Haemonchus contortus larvae exposed to four tropical tanniniferous plant extracts. Vet. Parasitol. 2008, 153, 313-319. [CrossRef] [PubMed]

94. Vargas-Magaña, J.J.; Torres-Acosta, J.F.J.; Aguilar-Caballero, A.J.; Sandoval-Castro, C.A.; Hoste, H.; Chan-Pérez, J.I. Anthelmintic activity of acetone-water extracts against Haemonchus contortus eggs: Interactions between tannins and other plant secondary compounds. Vet. Parasitol. 2014, 206, 3-4. [CrossRef]

95. Castañeda-Ramírez, G.S.; Rodríguez-Labastida, M.; Ortiz-Campo, G.I.; González-Pech, P.G.; Ventura-Cordero, J.; Borges-Argaéz, R.; Torres-Acosta, J.F.J.; Sandoval-Castro, C.A.; Mathieu, C. An in vitro approach to evaluate the nutraceutical value of plant foliage against Haemonchus contortus. Pararasitol. Res. 2018, 117, 3979-3991. [CrossRef] [PubMed]

96. López-Aroche, U.; Salinas-Sánchez, D.O.; Mendoza de Gives, P.; López-Arellano, M.E.; Liebano-Hernández, E.; Valladares-Cisneros, G.; Arias-Ataide, D.M.; Hernández Velázquez, V. In vitro nematicidal effects of medicinal plants from the Sierra de Huautla, Biosphere Reserve, Morelos, Mexico against Haemonchus contortus infective larvae. J. Helminthol. 2008, 82, 25-31. [CrossRef] [PubMed]

97. Espinosa-Moreno, J.; Centurión-Hidalgo, D.; Vera y Cuspinera, G.G.; Pérez-Castañeda, E.; Zaragoza-Vera, C.V.; Martínez-Martínez, S.; Mendoza-de-Gives, P.; González-Cortázar, M. Actividad antihelmíntica in vitro de tres especies vegetales utilizadas tradicionalmente en Tabasco, México. Polibotanica 2016, 4, 91-100. [CrossRef] 
98. García, J.E.; Gómez, L.; Mendoza-de-Gives, P.; Rivera-Corona, J.L.; Millán-orozco, J.; Ascacio, J.A.; Medina, M.A.; Mellado, M. Anthelmintic efficacy of hydro-methanolic extracts of Larrea tridentata against larvae of Haemonchus contortus. Trop. Ani. Health Prod. 2018, 50, 1099-1105. [CrossRef] [PubMed]

99. Palacios-Landín, J.; Mendoza-de Gives, P.; Salinas-Sánchez, D.O.; López-Arellano, M.A.; Liébano-Hernández, E.; Hernández-Velázquez, V.M.; Valladares-Ciscneros, M.A. In vitro and in vivo nematocidal activity of Allium sativum and Tagetes erecta extracts against Haemonchus contortus. Türkiye. Parazitol. Derg. 2015, 39, 260-264. [CrossRef] [PubMed]

100. Zamilpa, A.; García-Alanís, C.; López-Arellano, M.E.; Hernández-Velázquez, V.M.; Valladares-Cisneros, M.G.; Salinas-Sánchez, D.O.; Mendoza-de Gives, P. In vitro nematicidal effect of Chenopodium ambrosioides and Castela tortuosa $n$-hexane extracts against Haemonchus contortus (Nematoda) and their anthelmintic effect in gerbils. J. Helminthol. 2018, 1-6. [CrossRef] [PubMed]

101. De Jesús-Gabino, A.F.; Mendoza-de Gives, P.; Salinas-Sánchez, D.O.; López-Arellano, M.E.; Liebano-Hernández, E.; Hernández-Velázquez, V.M.; Valladares-Cisneros, G. Anthelmintic effects of Prosopis laevigata $n$-hexanic extract against Haemonchus contortus in artificially infected gerbils (Meriones unguiculatus). J. Helminthol. 2010, 84, 71-75. [CrossRef] [PubMed]

102. González-Cortazar, M.; Zamilpa, A.; López-Arellano, M.E.; Aguilar-Marcelino, L.; Reyes-Guerrero, D.E.; Olazarán-Jenkins, S.; Ramírez-Vargas, G.; Olmedo-Juárez, A.; Mendoza-de-Gives, P. Lysiloma acapulcensis leaves contain anthelmintic metabolites that reduce the gastrointestinal nematode egg population in sheep faeces. Comp. Clin. Pathol. 2018, 27, 189-197. [CrossRef]

103. Hernández-Villegas, M.M.; Borges-Argáez, R.; Rodríguez-Vivas, R.I.; Torres-Acosta, J.F.J.; Cáceres-Farfán, M. In vivo anthelmintic activity of Phytolacca icosandra against Haemonchus contortus in goats. Vet. Parasitol. 2012, 189, 284-290. [CrossRef] [PubMed]

104. González-Cruz, B.J.; Rodríguez-Labastida, M.; González-Cortázar, M.; Zamilpa, A.; López-Arellano, M.E.; Aguilar-Marcelino, L.; González-Garduño, R.; Torres-Acosta, J.F.J.; Olmedo-Juárez, A.; Mendoza-de Gives, P. In vitro larvicidal and in vivo anthelmintic effects of Oxalis tetraphylla (Oxalidaceae) hydroalcoholic extract against Haemonchus contortus in lambs. J. Helminthol. 2018, 92, 309-316. [CrossRef] [PubMed]

105. León-Castro, Y.; Olivares-Pérez, J.; Rojas-Hernández, S.; Villa-Mancera, A.; Valencia-Almazán, M.T.; Hernández-Castro, E.; Cordova-Izquierdo, A.; Jiménez-Guillen, R. Effect of three fodder trees on Haemonchus contortus control and weight variations in kids. Eco. Rec. Agro. 2015, 2, 193-201.

106. Alonso-Díaz, M.A.; Torres-Acosta, J.F.J.; Sandoval-Castro, C.A.; Capetillo-Leal, C.; Brunet, S.; Hoste, H. Effects of four tropical tanniniferous plant extracts on the inhibition of larval migration and the exsheathment process of Trichostrongylus colubriformis infective stage. Vet. Parasitol. 2008, 153, 187-192. [CrossRef] [PubMed] 